\title{
Natural and artificial routes to pluripotency
}

\author{
WINFRIED H. KRUEGER ${ }^{1,2,4}$, LINDSEY C. SWANSON ${ }^{3,4}$, BORKO TANASIJEVIC ${ }^{3,4}$ \\ and THEODORE P. RASMUSSEN*,1,2,3,4

\begin{abstract}
${ }^{1}$ Department of Pharmaceutical Sciences, School of Pharmacy, University of Connecticut, ${ }^{2}$ University of Connecticut Stem Cell Institute, University of Connecticut, ${ }^{3}$ Department of Molecular and Cell Biology, University of Connecticut and ${ }^{4}$ Center for Regenerative Biology, University of Connecticut, USA
\end{abstract}

\begin{abstract}
Pluripotent cells of the blastocyst inner cell mass (ICM) and their in vitro derivatives, embryonic stem (ES) cells, contain genomes in an epigenetic state that are poised for subsequent differentiation. Their chromatin is hyperdynamic in nature and relatively uncondensed. In addition, a large number of genes are expressed at low levels in both ICM and ES cells. Also, the chromatin of naturally pluripotent cells contains specialized histone modification patterns such as bivalent domains, which mark genes destined for later developmentally-regulated expression states. Female pluripotent cells contain $X$ chromosomes that have yet to undergo the process of $X$ chromosome inactivation. Collectively, these features of very early embyronic chromatin are required for the successful specification and production of differentiated cell lineages. Artificial reprogramming methods such as somatic nuclear transfer (SCNT), ES cell fusion-mediated reprogramming (FMR), and induced pluripotency (iPS) yield pluripotent cells that recapitulate many features of naturally pluripotent cells, including many of their epigenetic features. However, the route to pluripotent epigenomic states in artificial pluripotent cells differs drastically from that of their natural counterparts. Here, we compare and contrast the differing routes to pluripotency under natural and artificial conditions. In addition, we discuss the intrinsically metastable nature of the pluripotent epigenome and consider epigenetic aspects of reprogramming that may lead to incomplete or inaccurate reprogrammed states. Artificial methods of reprogramming hold immense promise for the development of autologous cell graft sources and for the development of cell culture models for human genetic disorders. However, the utility of artificially reprogrammed cells is highly dependent on the fidelity of the reprogramming process and it is therefore critically important to assess the epigenetic similarities between embryonic and induced pluripotent stem cells.
\end{abstract}

KEY WORDS: reprogramming, pluripotency, gametogenesis, preimplantation development, epigenetics

\section{Introduction}

Post-translational modifications (PTMs) of histones $\mathrm{H} 3$ and $\mathrm{H} 4$, substitution of canonical histones with variants, and cytosinemethylation of genomic DNA all participate in the epigenetic regulation of eukaryotic gene expression. Histone PTMs consisting of mono-, di-, and tri-methylation (me1, me2, me3) and acetylation (ac) are added to lysine $(K)$ and arginine $(R)$ residues located primarily in the $\mathrm{N}$-terminal tails of histones, which protrude from the compact globular cores of nucleosomes. Constitutive heterochromatin contains abundant H3K9me2, H3K9me3, H3K79me3, and H4K20me, while conditionally silenced facultative heterochromatin contains H3K27me2, H3K27me3, $\mathrm{H} 2 \mathrm{BK} 5 \mathrm{me} 3$. Actively transcribed euchromatin contains $\mathrm{H} 3 \mathrm{~K} 4 \mathrm{me}$,
H3K4me3, H3K9me, H3K27me, H3K79me, H3K79me2, H2BK5me, H3K9ac, H3K14ac, H4K5ac, H4K8ac H4K12ac and H4K16ac (Bernstein et al., 2002, Eberharter and Becker, 2002,

\footnotetext{
Abbreviations used in this paper: ESC, embrynonic stem cell; FISH, fluorescent in-situ hybridization; FMR, fusion mediated reprogramming; GO, Geneontology; HAT, Histone acetyl transferase; HDAC, Histone deacetylase; ICM, inner cell mass; ICR, imprinting control region; iPS, induced pluripotent stem cells; Jmjd, Jumonji; Me1, mono-methylation; Me2, dimethylation; Me3, tri-methylation; PGC, primordial germ cell; PID,preimplantation development; PRC, polycomb repressor complex; PTM, posttranslational modification; SCNT, somatic cell nuclear transfer; XCI, X chromosome inactivation; XCR, X chromosome reactivation; ZGA, zygotic genome activation.
}

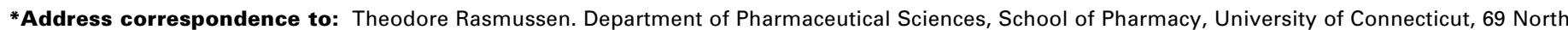
Eagleville Road, Storrs CT 06269, USA. Fax: +1-860-486-1553. e-mail: Theodore.Rasmussen@uconn.edu
}

Final author corrected PDF published online: 17 February 2011.

ISSN: Online 1696-3547, Print 0214-6282

(C) 2011 UBC Press

Printed in Spain 
Kubicek et al., 2006). Most histone methylation is imposed by SET domain-containing histone methyltransferases, while removal of methyl marks is performed by Jumonji domain (Jmjd) containing histone demethylases (Takeuchi et al., 2006). Acetylation usually facilitates transcription and is effected by histone acetyltransferases (HATs), while removal of acetyl groups is performed by histone deacetylases (HDACs). Modification states of specific lysine and arginine residues (by methylation or acetylation) directly influence transcriptional activity, and residuespecific methylation and acetylation states are regulated dynamically by the balance between histone methyltransferase/ demethylase and HAT/HDAC activities, respectively. Other PTMs include ubiquitination, sumoylation, and phosphorylation, and these often have functions other than transcriptional control. Strikingly, many of the enzymes required for the formation of specific PTMs are controlled by transcription factors tightly linked to the induction and maintenance of pluripotency, both in vitro and in utero. In addition, substitution of canonical histones with variants including but not limited to macroH2A, H1t, H1FOO, H3.3 ( $\mathrm{Ng}$ and Gurdon, 2008a) provides a further layer of molecularepigenetic complexity. This review illustrates how epigenetic and transcriptional mechanisms cooperate during normal reproductive biology and early development to produce toti- and pluripotent cells, and how similar pluripotent states are achieved via artificial reprogramming methods.

\section{The genetic and epigenetic basis for pluripotency}

Most notable among the genes expressed specifically in stem cells are the master pluripotency transcription factors Oct3/4/ Pou5F1 (Scholer et al., 1989a), Sox2 (Avilion et al., 2003), and Nanog (Chambers et al., 2003). This set of master regulators controls the expression of downstream genes required for maintenance of pluripotency and repression of differentiation (Boyer et al., 2005; Li, 2010). Oct4 is a universally required pluripotency factor, since pluripotent ICM cells cannot form in Oct4-/- mice (Nichols et al., 1998). Furthermore, Oct4 expression levels are finely tuned and reduced or increased Oct4 expression induces differentiation to trophoectoderm and primitive endoderm lineages, respectively (Niwa et al., 2000). Knockdown of Oct4 by RNAi causes more extensive changes in gene expression than knockdown of Sox2, Nanog or Rex1 (Grinnell and Bickenbach, 2007; Ivanova et al., 2006), though these transcription factors are equally important in maintenance of pluripotency. Oct4 binds to the octamer consensus sequence ATGCAAAT and analysis of chromatin immunopreciptation (ChIP) data has identified more than 400 putative Oct4 target genes which also tend to recruit Sox2 and Nanog (Chavez et al., 2009; Li, 2010; Sharov et al., 2008). Sox2, an HMG box domain protein, is regulated by Oct4 (Grinnell et al., 2007) and binds to its cognate promoters both by itself and in a complex with Oct4. Sox2, complexed with Oct4, binds to target promoters with bipartite POU/HMG regulatory elements that are typically separated by a three base-pair spacer. However, Sox2 can independently regulate Oct4 levels in embryonic stem cells (ESCs), and ESCs devoid of Sox2 differentiate into trophoectoderm-like structures similar to those observed in ESCs with reduced Oct4 expression. Nanog, a homeodomain transcription factor that binds to the TAAT $(\mathrm{G} / \mathrm{T})(\mathrm{G} / \mathrm{T})$ motif represents the most notable target gene of the Oct4/Sox 2 complex. It is required for maintenance of pluripotency (Yates and Chambers, 2005) and Nanog dimers confer cytokine-independent selfrenewal after overexpression in ESCs (Mullin et al., 2008). Moreover, Nanog is also a critical regulator of cell fate decisions including the repression of primitive endoderm formation (Chambers et al., 2003). In contrast to Oct4 deficiency, down-regulation of Nanog only predisposes ESCs for differentiation (Hyslop et al., 2005) and Nanog-/- ESCs can still self renew (Chambers et al., 2007). Nanog regulation is complex and includes promoter regulation by Oct4 and Sox2, as well as FoxD3 and p53 and the growth factors LIF, BMP, and Wnts (Pan and Thomson, 2007). Downstream targets of Nanog include the orphan nuclear receptor estrogen-related receptor beta (Esrrb), which in turn participates in an autoregulatory self-renewal feedback loop mediated through interactions of Esrrb with Oct4 and Sox2 (van den Berg et al., 2008).

Several studies of the transcriptional pluripotency network controlled by the Oct4-Sox2-Nanog set (Boyer et al., 2005; Chavez et al., 2009; Loh et al., 2006; Matoba et al., 2006; Sharov et al., 2008) identified more than 1400 putative and confirmed target genes that can be subdivided into four broad groups (Fig. 1 ): transcription factors, chromatin remodeling factors (including polycomb genes), cell cycle regulators, and suppressors of signaling. The Oct4-Sox2-Nanog triad mostly functions as a positive transcriptional regulator and only some 40 genes out of the 1400 are repressed by the triad complex. Many of the up-regulated genes are involved in the repression of transcription factors that can induce cellular differentiation (Fig. 1). In addition, some telomere-associated proteins including Terf 1 , Terf 2 and RIF are also up-regulated by the pluripotency master regulators. Sall4, a recently discovered pluripotency factor (Zhang et al., 2006), emerges as a factor equally critical to pluripotency since it shares the Oct4-Sox2-Nanog target gene set and also has been implicated in the control of Oct4 expression (Yang et al., 2008). We performed a meta-analysis of the combined data from these studies using gene-ontology (GO) classification for molecular function and identified a comprehensive collection of genes that is intrinsically linked to the organization of chromatin (Fig. 1). This gene collection includes the Jumonji domain containing histone H3K9 lysine demethylases $1 \mathrm{~A}, 1 \mathrm{C}$, and $2 \mathrm{C}$, and the H3K4 demethylase Jarid1b. Remarkably, regulators for bivalent domain modification are also among the target genes and include Jarid2, Suz12, Cylp, and Aebp2. Suz12 encodes a core protein of the repressive polycomb repressive complex 2 (PRC2), whereas the latter two proteins interact peripherally with PRC2. JARID2 binds to more than $90 \%$ of PRC2 target genes and functions in the methylation of H3K27 (Pasini et al., 2008; Li et al., 2010). Together with the positive regulation of the H3K4 methyltransferase SETD1B and the H3K9 specific methyltransferase EHMT1, this suggests that expression of the Oct4-Sox2-Nanog pluripotency triad alone may be sufficient to regulate enzymes necessary to establish bivalent domains in ESC chromatin. Further control over differentiation-associated gene expression is exerted through upregulation of the H3K9 methyltransferase SETD1B/KMT1E, which is especially required for repression of trophoectoderm specific gene expression (Lohmann et al., 2009). Moreover, KMT1E also suppresses other lineage differentiation markers, many of which overlap with known targets for PRC2 mediated repression suggesting that KMT1E and PRC2 complexes control 
gene expression in concert. The Oct4-Sox2-Nanog triad also regulates histone methyltransferases with transcription-promoting functions including those imparting H3K4 methylation. Among these are chromodomain helicase DNA binding protein 7 (CHD7), which marks H3K4 methylation (Schnetz et al., 2009), the CXXC finger protein Cfp1, which is required for targeting of the H3K4 methyltransferase SET1D1A (Tate et al., 2010) and the histone acetyltransferase MYST2, which is associated with transcriptionally active chromatin (Utley and Cote, 2003). Together, this analysis demonstrates that pluripotent cells contain a rich and diverse epigenetic machinery and that their combined expression

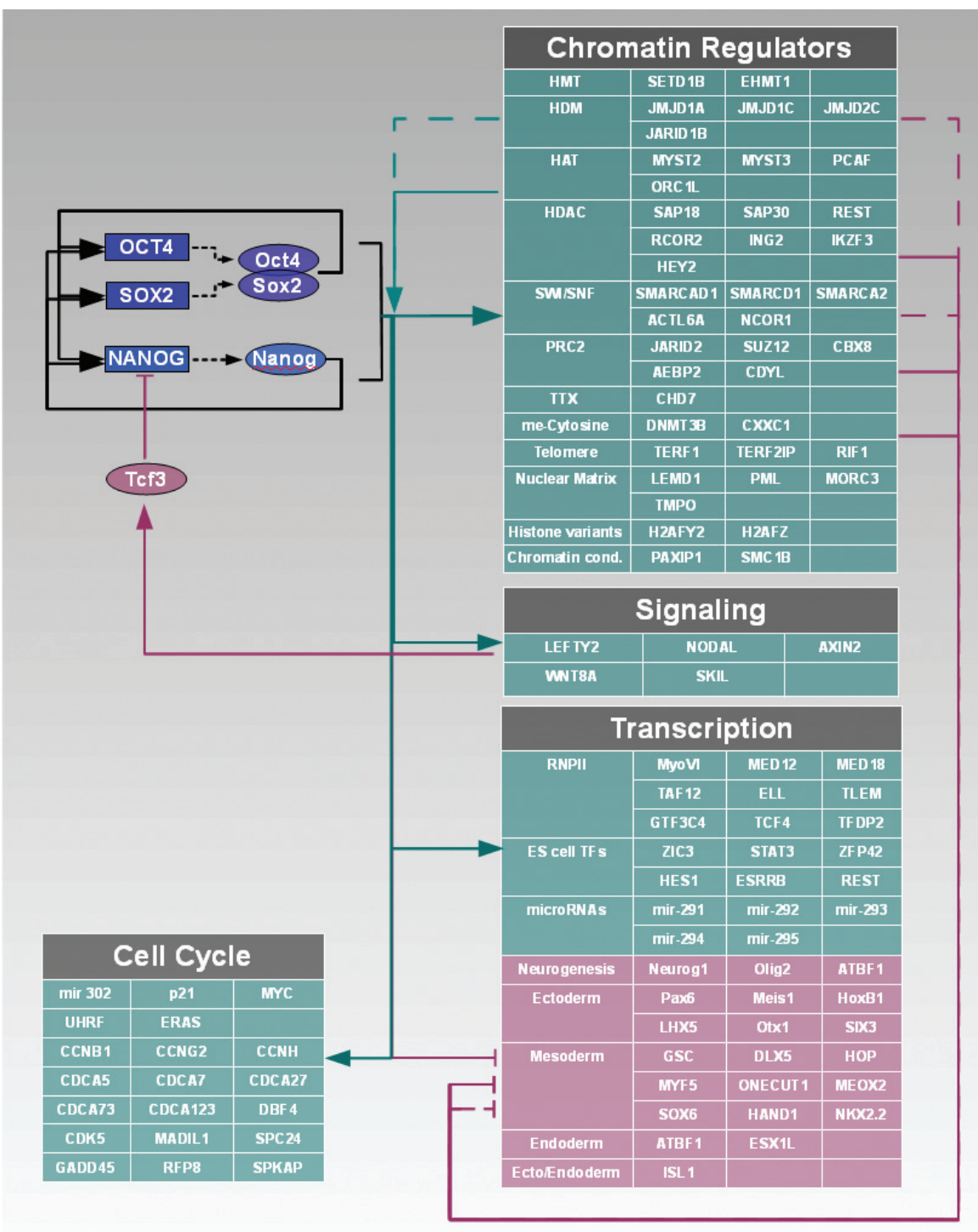

Fig. 1. ES cell pluripotency network. The subset of target genes for Oct4, Sox2 and Nanog shown was selected from more than 1400 genes identified in five recent studies (Chavez et al., 2009; Matoba et al., 2006; Sharov et al., 2008; Loh et al., 2006; Boyer et al. 2005). The selection was based on classification for function by gene-ontology (GO)-terms. Target genes in green boxes are up-regulated by the pluripotency factors whereas those in red are down-regulated. Solid lines indicate that all members within a subgroup regulate transcription in the same way whereas hatched lines indicate that subgroups contain members that either up- or downregulate transcription. is controlled by the Oct4-Sox2-Nanog network alone.

The Oct4-Sox2-Nanog triad may also contribute to the higher basal levels of transcription observed in ESCs by positively regulating several RNA polymerase II (RNPII) associated factors (Chavez et al., 2009). These may alter the RNPII core enzyme structure and confer increased polymerase initiation and elongation rates. The most prominent members of this group are Myosin VI (associated with enhanced RNP II transcription rates), the mediators of RNPII transcription Med12 and Med18, the elongation factors Ell and Tcea1, the TATA-box binding protein Taf12 and the general transcription factors GTF3C4, TCF4 and TFDP2 (Chavez et al., 2009). Oct4, Sox2 and Nanog also control microRNA expression, notably including those encoded by the miR-290-295 and 302 clusters, which together may regulate several hundred target messenger RNAs and counteract non-specific transcription through the microRNA controlled regulation of translation (Gunaratne, 2009). Open chromatin and high rates of basal transcription may also contribute to the control of certain chromatin modifiers including H3K4-specific histone methyltransferases (Buratowski, 2009). This may occur through their association with phosphorylated serines 2 and 5 of the RNPII C-terminal domain (CTD), which facilitates targeting to specific genomic loci through binding of RNPII to promoter sequences and provides a feedback loop that reinforces the open chromatin conformation (Buratowski, 2009). Moreover, this mechanism places the respective histone methyltransferases under the control of the Serine 2- and 5-specific cell cycle dependent kinases CDK 7 and 9, respectively, aiding in the marking with both transcription enhancing $\mathrm{H} 3 \mathrm{~K} 4 \mathrm{me}$ and transcription repressing H3K27me marks. The affected genes form the group of so-called bivalent domain genes and encompass key regulators essential for cell fate decisions during embryogenesis (Bernstein et al., 2006). They are bound by the polycomb repressive complexes 1 (PRC1) and 2 (PRC2), and in ESCs, nucleosomes linked to them contain the histone variant H2A.Z (Creyghton et al., 2008). RNPII associates with bivalent domain genes in an elongation primed configuration but pauses at promoter-proximal sites due to the absence of Serine 2 phosphorylation and indirectly, PRC-mediated H2A ubiquitination (Brookes and Pombo, 2009). Therefore, the regulation of RNPII-associated factors may aid in the formation of transcription complexes that are less repressive of gene expression.

Evidence exists indicating that lamin based nuclear organization counteracts pluripotency. ESCs contain a reduced content of heterochromatin and its structure is hyperdy- 
namic as evidenced by the short fluorescence recovery times after photobleaching of GFP-tagged nuclear proteins (Meshorer et al., 2006). This may be due to the absence of A-type Lamins in ESCs (Constantinescu et al., 2006), members of an intermediate filament family that are essential for the maintenance of the nuclear architecture. A-type lamins provide a regulatory scaffold for numerous activities at both the nuclear envelope and in the central nucleoplasm (Gotzmann and Foisner, 1999; Han et al., 2008b; Lloyd et al., 2002; Maraldi et al., 2008; Melcon et al., 2006; Prokocimer et al., 2009). For example, lamins provide docking sites for $\mathrm{H} 2$ histones and, by virtue of the Barrier-to-Autointegration Function (BAF) protein, also to Histone H3 (Goldberg et al., 1999; Mattout et al., 2007; Montes de Oca et al., 2005). These interactions, in addition to ones facilitated by other lamin binding proteins, are thought to play a fundamental role in the control of subnuclear heterochromatin localization (Gruenbaum et al., 2005). Recent data show that A-type lamins associate with many transcription factors including SREBF1/F2, RB1, several SMAD proteins, the ING class of PHD finger proteins (Andres and Gonzalez, 2009; Worman, 2006) and new interactions with unidentified transcription factors are likely. Both, lamin-chromatin and lamintranscription factor associations result in the stabilization of DNAprotein interactions and provide a mechanism for lamin based control of RNA polymerase II transcription. Consistent with this hypothesis, ablation of A-type lamins in somatic cells is associated with a generalized upregulation of transcription (Parnaik, 2008).

In ESCs, A-type lamins are up-regulated during the exit from pluripotency prior to the silencing of Oct4 (Constantinescu et al., 2006). The absence of lamins in ESCs is thought to destabilize DNA-protein interactions, resulting in the observed continuous fluctuation of DNA-protein associations and low-level expression of large numbers of genes which contributes to pluripotency by enabling responses to greater numbers of environmental signals in ESCs.

In summary, the Oct4-Sox2-Nanog triad appears to be sufficient for the basal pluripotency feedback circuitry, control of the ES cell cycle, open chromatin organization, high basal ESC transcription rates and suppressive marking of key differentiation genes in bivalent chromatin domains. Upregulation of chromatin modifiers and numerous transcription factors play a large role in this process, which may be reinforced by the greatly decreased expression of lamin $A / C$ in pluripotent stem cells.

\section{Reprogramming during germ line maturation and ga- metogenesis}

Expression of Oct4, Sox2 and Nanog is required for the formation of a new organism from a single cell but in somatic cells these factors are not expressed together. For instance, Oct4 appears in significant amounts only in the germ line and key pathways required for proper embryonic development may be epigenetically pre-coded during gametogenesis. After packaging with protamines, a small but significant fraction of canonical histones remain associated with the paternal genome, and they associate predominantly with genomic loci that are vital for embryogenesis including those encoding key embryonic transcription factors, signaling proteins and promoters of miRNAs (Hammoud et al., 2009b). This striking finding suggests that some embryonic gene expression may be epigenetically pre-coded in the male germ line before fertilization. It also suggests a biphasic natural route to the reprogrammed epigenome consisting of a first phase of pre-patterning which occurs during gametogenesis and a second phase of active reprogramming which spans preimplantation development. Plausibly, during the first pre-patterning phase, the somatic epigenome may be subdivided into a fraction essential for post-fertilization development, one for post gastrulation-development and one containing genes that interfere with the formation of toti- and pluripotent cells (Carrell and Hammoud, 2010). During preimplantation development, the second phase, the pronuclear epigenomes are reprogrammed to the totipotent state of the zygote and ensuing cleavages give rise to the pluripotent cells of the ICM (Fig. 2). X chromosome reactivation and inactivation $(\mathrm{XCR} / \mathrm{XCl}$ ) for gene dosage compensation due to the presence of two sex chromosomes (Lyon, 1961) also occurs during gametogenesis and ensuing preimplantation development and represents one of the most prominent examples for natural reprogramming.

\section{Resetting the somatic genome in primordial germ cells}

Primordial germ cells (PGCs), the precursors of all germ cells, arise from the ICM in the proximal part of the epiblast shortly prior to gastrulation. PGC-specific changes in histone methylation occur as early as during the specification of the PGC fate, as evidenced by the PGC-specific expression of the transcription repressing histone methyltransferase Prdm1/Blimp1 (Tunyaplin et al., 2000; Turner et al., 1994). Expression of this histone methyltransferase during PGC-genital ridge migration facilitates di-methylation of histones H2AR3 and H4R3 (Ancelin et al., 2006), which may aid in maintaining PGCs in an undifferentiated state (John and Garrett-Sinha, 2009). The action of Blimp1 for PGC-specific gene silencing involves the recruitment of the Groucho-complex (Ren et al., 1999) and histone deacetylase activity to specific genomic loci (Yurke et al., 2000) including Hox genes (Ohinata et al., 2005).

During maturation of PGCs to mature gametes, sequential epigenetic changes occur during the mitotic and meiotic cell divisions that distinguish the differentiated cells of the germ line from all other somatic cells. This cascade includes global changes in DNA and histone methylation, imprinting, and substitution of canonical histones with gamete-specific varieties (Godmann et al., 2009). In mouse, PGCs arrive at the genital ridge in a globally DNA-hypomethylated state (Monk, 1987) and are then are rapidly remethylated (Hajkova et al., 2002). Imprinted regions remain hypomethylated until day E13.5 (Lee et al., 2002). The wave of gametic methylation peaks around E15.5 in the male mouse embryo, and is complete by birth (Fig. 2). Mature gametes remain highly methylated until fertilization (Lees-Murdock and Walsh, 2008). Consistent with the transcription enabling role of the H3K4 methylation, this mark remains excluded from genomic regions with high levels of DNA methylation (Tate et al., 2010). Oogonia remain hypomethylated until maturation into oocytes (Lucifero et al., 2004; Obata et al., 2002), whereas the spermatogonial DNA including retrotransposons (Monk, 1987) and imprinting control regions (ICRs) is already de novo methylated at the mitotically arrested prospermatogonial stage (Davis et al., 2000; Ueda et al., 2000).

A recent gene expression study performed with both 
prospermatogonia and pachytene oogonia at E15.5 in mice identified several highly expressed constituents of the epigenetic machinery required for sequence-specific gene silencing (Lefevre and Mann, 2008). These include the de novo DNA methyltransferase genes Dnmt3a, Dnmt3b, and the Dnmt3a activity enhancing Dnmt3/ (Bourc'his and Bestor, 2004; Bourc'his et al., 2001; Chen and Riggs, 2005; Hata et al., 2002; Kaneda et al., 2004; Lehnertz et al., 2003; Webster et al., 2005), as well as the maintenance DNA methyltransferase Dnmt1, albeit at lower expression levels. The CCXC finger 1 (PHD domain) gene Cxxc1/ Cfp1 represents one of the most strongly expressed genes in prospermatogonia and encodes a CpG binding protein (Tate et al., 2010). Its spermatogonial function is unknown, but in ESCs, it is required for DNMT1-mediated maintenance of global DNA methylation (Carlone et al., 2005) but its function in spermatogonia requires additional investigation. Further chromatin modifiers present in prospermatogonia at significant levels include the H3K9 and K27 methyltransferases Ehmt1 and 2 (Eukaryotic histone methyltransferase and Eukaryotic histone Iysine methyltransferase N 2/G9a) (Lefevre and Mann, 2008). G9a interacts with Dnmt1 and both Dnmt3s, thereby stimulating their activities during prenatal testis development (Esteve et al., 2006) and aiding in the silencing of selected target sequences including Oct4 (Fig. 2) (Feldman et al., 2006), retrotransposons and imprint- ing control regions (ICRs) (Mann et al., 2000; Racedo et al., 2009). Two additional SET domain-containing histone methyltransferases, Ezh1 (enhancer of zeste homologue) and Setd1b (SET domain, bifurcated 1), are also up-regulated in progametogonia and contribute to sequence specific H3K9 and H3K27 methylation (Lefevre and Mann, 2008).

In concert with the increased levels of repressive histone marks during male germline development, several effectors of H3K9 and H3K27 methylation are also up-regulated in progametogonia including the chromodomain helicase DNA binding proteins Chd1I, Chd5 and the Tudor domain proteins Tdrd5 and 9, which also interact with $\mathrm{H} 3 \mathrm{~K} 79$ during DNA repair (Lefevre and Mann, 2008). A number of histone demethylases are expressed at significant levels, including the H3K4 demethylase amine oxidase (flavin containing) domain 2 (Aof2) (Shi et al., 2004a), the jumonji domain proteins Jarid2, Jarid1b, and the H3K9 demethylase Jmjd1a. Finally, in spermatogonia, the chromatin regulator Wdr45I, a WD-repeat containing protein required for conversion of $\mathrm{H} 3 \mathrm{~K} 4 \mathrm{me} 2$ to the transcription promoting H3K4me3 mark (Dillon et al., 2005; Martin and Zhang, 2005) is also up-regulated, consistent with the high level of H3K4 methylation in these cells. Reestablishment of erased paternal imprints also occurs during male germ line development after biallelic expression in PGCs (Weaver et al., 2009) and is completed at the
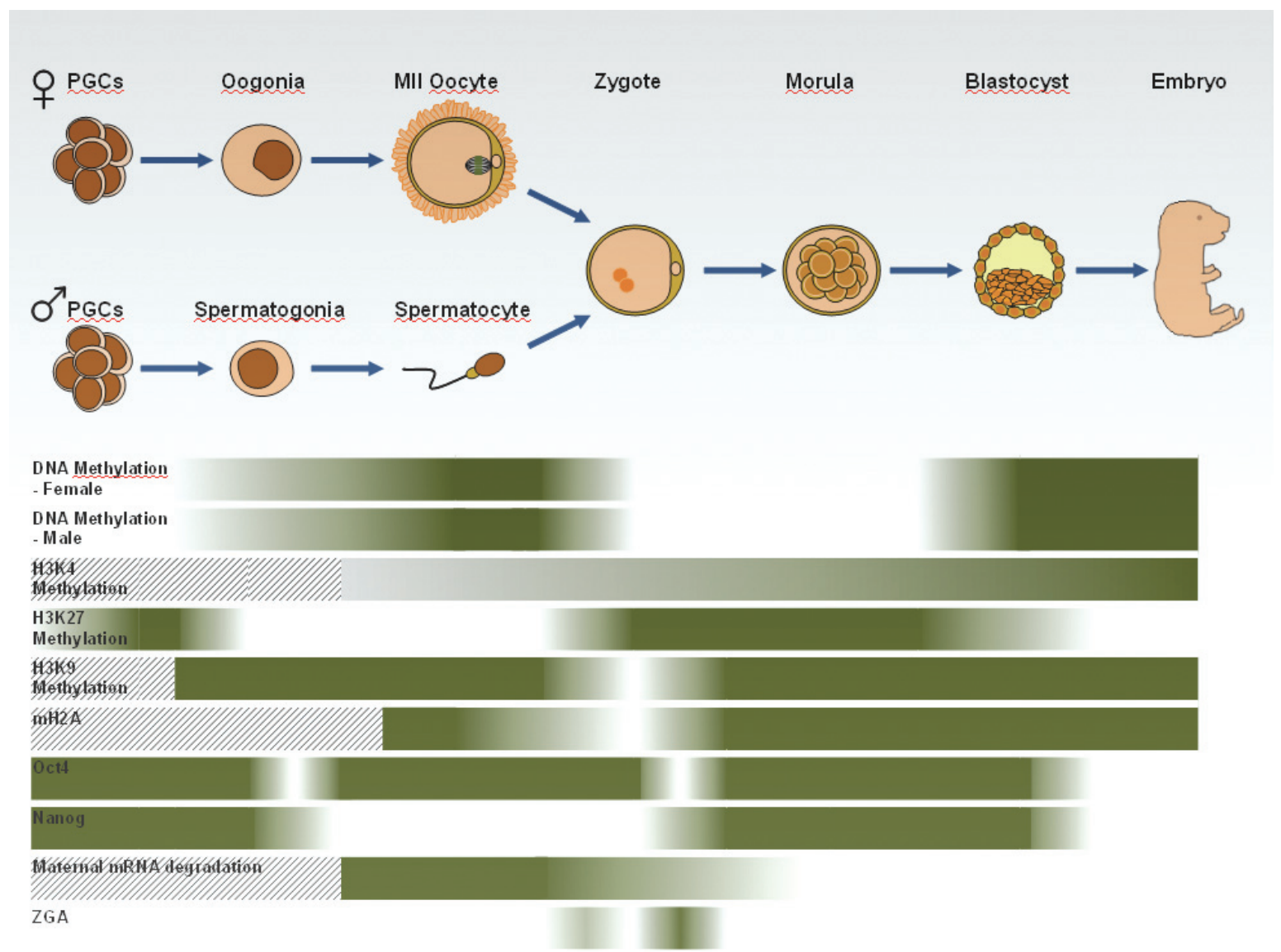

Fig. 2. Epigenetic changes during natural reprogramming. Epigenetic profiles are represented qualitatively and were assembled from data published previously (Reik 2007; Chang et al., 2005; Zernicka-Goetz et al., 2009; Shi and Wu, 2009). Hatched sections denote the absence of information regarding the expression status during this time. 
time of birth (Szabo and Mann, 1995). Imprinted loci frequently occur in clusters near imprinting control regions (ICRs) consisting of larger CpG islands (Ferguson-Smith and Surani, 2001; Reik and Walter, 2001), but only a small subset of all known ICRs are imprinted in the paternal germ line (Delaval and Feil, 2004) including the H19/IGF2/miR-675/miR-483 cluster (Peters and Robson, 2008; Thorvaldsen et al., 1998), the Dlk1-Gtl2 cluster (Lin et al., 2003) and the Rasgrf1 locus (Yoon et al., 2002). The explicit mechanism for prenatal imprinting is not fully understood, but requires DNA methyltransferase 3A (Dnmt3A) (Kaneda et al., 2004) and postnatal marking of paternal ICRs through additional histone modifications during chromatin condensation (Delaval et al., 2007). Both imprinted loci and repetitive elements arising from retrotransposition (Whitelaw and Martin, 2001) are remethylated to prevent their transcription during gametogenesis. This process, which in mouse requires Dnmt3b, Dnmt3L and piwi-like proteins (Kuramochi-Miyagawa et al., 2008), is required for successful completion of meiosis (Ollinger et al., 2010).

Taken together, the above information demonstrates that epigenetic modulation is not only critical for germ line development and fertility, but may also have a previously underappreciated role in epigenetic pre-patterning for subsequent development after fertilization.

\section{Spermatogenesis}

During spermatogenesis all canonical DNA methyltransferases (Dmnts) are expressed and the spermatocyte DNA methylome resembles that of ES cells (Eckhardt et al., 2006; Farthing et al., 2008; Oakes et al., 2007). DNA methylation increases significantly throughout spermatogenesis but numerous promoters with low-density $\mathrm{CpG}$ islands remain hypomethylated, including many of the Oct4, Sox2 and Nanog target genes (Farthing et al., 2008; Illingworth et al., 2008). In contrast, the Oct4, Sox2 and Nanog genes themselves are methylated during spermiogenesis (Feldman et al., 2006). Consistent with transcriptional silencing of the paternal genome during spermatogenesis, loss of the H3K4 demethylase Lsd1 (Katz et al., 2009; Shi et al., 2004b) causes germ cell apoptosis and sterility. Moreover, H3K9 and H3K27 methylation increases globally during meiosis, drop to an intermediate level and remain stable thereafter (Fig. 2)(Payne and Braun, 2006).

Further chromatin remodeling during spermatogenesis includes histone replacement in which a portion of canonical histones are substituted with testis-specific variants. An initial wave occurs immediately prior to meiosis yielding the replacement of the linker histone $\mathrm{H} 1$ with the variant $\mathrm{H} 1 \mathrm{t}, \mathrm{H} 2 \mathrm{~B}$ with $\mathrm{H} \mathrm{H} 2 \mathrm{~B}$, $\mathrm{H} 2 \mathrm{~A}$ with $\mathrm{H} 2 \mathrm{~A} . \mathrm{Z}$ and $\mathrm{H} 3$ with $\mathrm{H} 3.3$. $\mathrm{H} 1 \mathrm{t}$ is thought to aid in chromatin decondensation (Sarg et al., 2009), tH2B may mark certain sperm maturation associated and ion channel genes, $\mathrm{H} 2 \mathrm{~A}$.Z becomes enriched at pericentromeric regions (Hammoud et al., 2009a; Hammoud et al., 2009b) and H3.3, which has been demonstrated to mark transcribed genes ( $\mathrm{Ng}$ and Gurdon, 2008a, $2008 b)$, may aid in the transmission of chromatin states for genes that are functionally essential for spermatogenesis and/or preimplantation development. Once the final epigenetic marks have been established more than $80 \%$ to $95 \%$ of the canonical histones are replaced by protamines 1 and 2 (Tanphaichitr et al., 1978; Wykes and Krawetz, 2003), which are required for maturation, fertility and extreme compaction of the paternal genome needed for packaging into the sperm head (Balhorn et al., 1988; Corzett et al., 2002). The ratio of the two protamines determines the success of preimplantation development (PID), unexpectedly indicating that the sperm epigenome is essential to PID (DepaMartynow et al., 2007). NURF301, an ISWI-containing chromatin remodeling complex catalyzing ATP-dependent nucleosome sliding and required for spermatogenesis, may aid in nucleosome arrangement in sperm (Kwon et al., 2009).

The histones remaining in mature sperm chromatin often harbor H3K4 and K27 modifications and include all four canonical histones and the testis-specific $\mathrm{H}$ 2B variant (Gatewood et al., 1990; Kimmins and Sassone-Corsi, 2005). Histone retention in sperm may mark the specific genomic regions for transcriptional regulation during PID. Consistent with this hypothesis, H3K4me2 and $\mathrm{H} 3 \mathrm{~K} 4 \mathrm{me} 3$ marks are enriched at certain coding and noncoding loci. Among the non-coding loci are promoters of noncoding RNAs, miRNAs and imprinted loci (Hammoud et al., 2009a; Hammoud et al., 2009b) and among the coding loci are genes required for RNA metabolism, spermatogenesis, nuclear reorganization and, notably, embryonic transcription factors (Hammoud et al., 2009a; Hammoud et al., 2009b). Many of the transcription factor genes also harbor the repressive H3K27 methylation mark (Bernstein et al., 2006; Hammoud et al., 2009a; Hammoud et al., 2009b; Ku et al., 2008). Intriguingly, numerous genes affected by DNA and histone methylation changes are targets of Oct4, Sox2 or Nanog in ES cells and the expression of Oct4, Sox2 and Nanog alongside Sall4 is essential for spermatogenesis (Choi et al., 2007; Krentz et al., 2009; Pesce et al., 1998; Scholer et al., 1989b). Their expression continues in the germ line until differentiation into gametogonia (Raverot et al., 2005) and both Oct4 and Nanog reappear postnatally in differentiated germ cells including spermatocytes and spermatids until puberty commences (Goel et al., 2008). These results further corroborate the hypothesis that paternal epigenome pre-patterning may have an underappreciated role in directing expression of pluripotency associated genes in PID reprogramming (Reik, 2007).

\section{Pre-patterning of the maternal epigenome}

Hypomethylated DNA is progressively remethylated during female PGC maturation, but this process may not involve Dnmt3L (Lucifero et al., 2007). However, in comparison to its male counterpart, the DNA remains globally hypomethylated (Fig. 2).

Histone methylation is also dynamically regulated during oogenesis. Levels of H3K4 methylation undergo stepwise increases during their maturation from day 10 post partum (pp), continue up to the germinal vesicle stage (GV-oocytes) (Kageyama et al., 2007) and are mostly paralleled by alterations in repressive H3K9 methylation (Fig. 2). Maintenance of H3K4 and K9 marks likely requires an active mechanism, given the observed rapid histone H3/H3.3 and H3.3 exchange (Stewart et al., 2006) and H3K9 trimethylation in male pronuclei upon their transfer into enucleated GV- or MII-stage oocytes (Liu et al., 2004). Histone acetylation and DNA methylation also increase during oocyte growth and closely parallel the changes in the $\mathrm{H} 3 \mathrm{~K} 4$ and $\mathrm{K} 9$ methylation levels, with the exception of GV-stage oocytes (Fig. 2). The increased H3K4 methylation and histone acetylation levels stand in contrast to the observed transcriptional silencing in maturing oocytes but are apparently not associated with increased locusspecific transcriptional activity (De La Fuente et al., 2004) there- 
fore reflecting more global alterations in chromatin organization (Debey et al., 1993; Zuccotti et al., 1995). One possibility is that the observed H3K4 methylation occurs at loci that are also H3K27 methylated, leading to the formation of bivalent domains (chromatin containing both H3K4me and H3K27me). To date, we are unaware of any studies addressing the existence of bivalent domains in oocytes.

Substitution of canonical histones also occurs in the female germ line and includes the oocyte specific histone variant $\mathrm{H} 1$ foo. $\mathrm{H} 1$ foo remains present in the ovum (Chang et al., 2005; Clarke et al., 1997; Tanaka et al., 2001) where it localizes primarily to the perinucleolar heterochromatin. Its ablation causes failure to extrude the first polar body, indicating that it is essential for oocyte maturation (Furuya et al., 2007) though its exact role is currently unknown.

X chromosome reactivation $(\mathrm{XCR})$ represents a major chromatin remodeling event and occurs in PGCs as early as E8.5. Once PGCs colonize the genital ridges (E10.5), the majority of them contain two active $X$ chromosomes $(X a)$ as indicated by the absence of Xist RNA, a marker for the inactive $\mathrm{X}$ chromosome (Xi; see below) (McLaren, 2003). However, XCR occurs stochastically, and XCR is still incomplete at E14.5 indicating a gradual process (Sugimoto and Abe, 2007), which may be analyzed more effectively in forthcoming vitro models for gametogenesis (Aflatoonian et al., 2009).

\section{Reprogramming and preimplantation development (PID)}

Progression to the second phase of natural epigenetic reprogramming commences with fertilization. The fertilization event triggers a series of $\mathrm{Ca} 2+$ oscillations that activate the egg, inducing completion of meiosis II and extrusion of the second polar body. The oscillation ends with the subsequent decondensation of paternal and maternal chromosomes and the formation of the male and female pronuclei (reviewed in (Swann et al., 2006)). Zygotic genome activation (ZGA) commences during this time and occurs as maternal stores of RNA and protein are degraded.

Soon after protamine removal and decondensation, the paternal DNA becomes demethylated, a condition that persists until the morula stage (Santos et al., 2002). Demethylation of the paternal genome occurs rapidly even in the absence of replication (Mayer et al., 2000; Oswald et al., 2000) and in mouse, rat, pig and cattle zygotes, but at the 16-cell stage in rabbit (Shi et al., 2004a). The mechanism for pronuclear DNA demethylation has not been identified, but candidate proteins include the DNA excision repair enzymes (Mendez-Acuna et al., 2010). Pronuclear DNA demethylation appears to represent the default pathway and protection from demethylation requires the maternal factor Stella /Pgc7. Further zygotic demethylation is likely the result of passive demethylation caused by DNA replication without access to the maintenance DNA methyltransferase Dnmt1 (Rougier et al., 1998), even though Dnmt1 protein is constitutively expressed (Cirio et al., 2008; Kurihara et al., 2008). Subtle differences exist for Dnmt1o expression in males and females which is active only during the eight cell stage after nuclear import. Female embryos contain the isoform whereas in male embryos alternative splicing prevents its translation, a situation which may account for the differences in maintenance of imprinted loci in male and female embryos (Cirio et al., 2008). Remethylation commences at the transition from morula to blastocyst but global DNA methylation levels may not be mechanistically critical; in mouse the extent of DNA methylation in the ICM exceeds that of the trophoectoderm (Santos et al., 2002) whereas in humans the opposite is observed (Fulka et al., 2004).

During sperm chromatin decondensation, substitution of protamines with canonical and variant histones is a prerequisite for subsequent demethylation and transcriptional activity of the male pronucleus (McLay and Clarke, 2003). The transcription-promoting histone variant 3.3 (Ahmad and Henikoff, 2002; Chow et al., 2005 ) is incorporated solely into the male pronucleus at the time of protamine substitution and remains enriched in the paternal chromatin for several cell divisions (Torres-Padilla et al., 2006; van der Heijden et al., 2005). This may aid in the transfer of the epigenetic code stored in the prepatterned male epigenome to the zygotic progeny during mitosis (Chow et al., 2005). In the maternal pronucleus, the unique histones $\mathrm{H} 1$ foo and macroH2A are down-regulated only after the first mitotic division (Chang et al., 2005). MacroH2A remains repressed until the morula stage and associates with the PRC2 complex (Buschbeck et al., 2009), indicating that its expression may be associated with gene silencing (Chang et al., 2005).

Several oocyte-derived proteins are critical for remodeling of sperm chromatin which coincides with the so-called minor phase of zygotic gene activation (Fig. 2) including nucleoplasmin 2, basonuclin, the transcription intermediate factor 1 (Tif1 $\alpha$ ) and the chromatin factor Brg1 (Minami et al., 2007; Sun et al., 2007; Torres-Padilla et al., 2006; Zernicka-Goetz et al., 2009). Nucleoplasmin 2 is required for protamine exchange and basonuclin stimulates RNPI and II transcription. Brg1/Smarca4 and Smarcc1/Baf155, subunits of the nucleosome remodeling complex Smarca5/Iswi/Snf2h, appear enriched in the male pronucleus (Aoki et al., 1997) and are critical for maintenance of H3K4me2 levels. Tif1a modulates expression of several genes in the zygote and is required for targeting of RNPII, Snf2 and Brg1. The composition of the ensuing new paternal epigenome remains strikingly distinct from its maternal counterpart. It is enriched in transcription promoting histone modifications and uniquely contains H3K4me and H4K20me (Kourmouli et al., 2004; van der Heijden et al., 2005). The preferential association of some of the maternally provided factors with the paternal genome may provide the critical link to the observed asymmetry between the parental epigenomes and form the molecular basis for the higher transcription rates from the paternal genome (Eberharter and Becker, 2002). Amplifying the effect of ooplasmic factors, which may ultimately account for the exclusive appearance of H3K4me in the paternal epigenome shortly after fertilization, is the presence of sperm derived H4K8ac and H4K12ac (Lepikhov and Walter, 2004; van der Heijden et al., 2006). H3K4me3 marks appear 8-10 hrs post-fertilization in mouse and parallel the de novo methylation of $\mathrm{H} 3 \mathrm{~K} 9$ which remains restricted to the monomethylated form in the paternal epigenome (van der Heijden et al., 2005). The appearance of these marks is accompanied by subsequent histone acetylation at residues H3K9, H3K14, H3K18, H4K5, H4K12 and H4K16 and by maintenance of paternal pronuclear H3K9 hypomethylation. The observed histone acetylation results from either substitution or acetylation of freshly incorporated histones by ovum-derived residual meiosis specific matura- 
tion factors (van der Heijden et al., 2006). The block of the ooplasmic H3K9 methylase (Liu et al., 2004) may be facilitated either by the H3K9me3 specific histone demethylase Jmjd2a (Katoh and Katoh, 2007) and/or through potential masking of paternal pronuclear H3K9me through loose association with the heterochromatin protein $1 \beta$ (HP1 $\beta$ ) (Santos et al., 2005).

Similarly and consistent with the heightened transcriptional activity in the paternal pronucleus, the paternal epigenome is hypomethylated at the H3K27 residue in the pronuclear stage (Erhardt et al., 2003b). However, it is unknown whether epigenetically prepatterned loci in the male pronucleus, which include HOX gene clusters, non-coding RNAs, paternally expressed imprinted loci and ES cell specific bivalent domain promoters (Hammoud et al., 2009b), are exempt from histone substitution. Further investigation of this issue is required to confirm the attractive hypothesis that exemption from substitution maintains their predisposition to gene expression at critical time points during development and prevents their activation outside of the required temporal sequence during embryogenesis.

The maternal pronuclear genome is less transcriptionally active (Adenot et al., 1997), its epigenome is hypoacetylated and it contains high levels of repressive H3K9me2 and H3K9me3 (Minami et al., 2007). Nevertheless, significant levels of the transcription enhancing H3K4me3 are present. Curiously, only maternal pronuclei contain the histone modifications H3K64me and H4K2Ome3 in zygotes. H4K20me3 is associated with constitutive heterochromatin including centromeric, pseudoautosomal and some telomeric regions (Kourmouli et al., 2004). In the zygote, trimethylation of H4K20, typically performed by the histone methyltransferase Suv420h1 and h2 appears to depend on Suv39h, an H3K9specific methyltransferase, providing a link between H3K9 and H4K20 trimethylation (Kourmouli et al., 2004; Puschendorf et al., 2008). Levels of H4K20me3 are reduced during the first mitotic division and remain fixed until the blastocyst stage (Kourmouli et al., 2004; van der Heijden et al., 2005) and, in conjunction with the paternal H3K4me, provide a mechanism by which the parental genomes can be distinguished. The role of trimethylated H3K64 is less well understood, but its reappearance is linked to blastocyst implantation (Daujat et al., 2009).

Completion of pronuclear restructuring culminates in major zygotic genome activation (ZGA) and completion of maternal RNA degradation (Schier, 2007; Schultz, 2002), which in mouse is paralleled by commencement of the first embryonic cell division. Species-specific differences in timing exist and indicate the requirement for completion of pronuclear chromatin reorganization into a state compatible with the ensuing totipotent transcriptome (Telford et al., 1990). This may also include the degradation of Atype lamins, supplied by the ovum and present in the early zygotic stage. Its degradation time course may represent one determinant for onset of ZGA. Support for this hypothesis stems from the observation that A-type lamin expression remains repressed until gastrulation (Foster et al., 2007; Hall et al., 2005; Houliston et al., 1988; Schatten et al., 1985). During ZGA, all circuitry essential for toti/pluripotency is up-regulated including the expression of Oct4, Sox2, Nanog and Sall4 which persists until the late blastula. The major ZGA is completed at the four-cell stage and while blastomeres at this stage contain equal levels of methylated histones their association with specific loci in different blastomeres has not yet been determined. Methylation of H3R17 and R26 is essential for the formation of totipotent blastomeres at least up to the fourcell stage since high levels of this epigenetic mark are required for the expression of pluripotency genes (Wu et al., 2009). Down regulation of the associated arginine-methylase coactivator associated methyltransferease 1 (Carm1) induces loss of pluripotency gene expression including Nanog and Sox2, resulting in subsequent differentiation, linking this enzyme mechanistically to the maintenance of pluripotency (Torres-Padilla et al., 2007; Wu et al., 2009).

The first cell fate decision is initiated after transition from the four-cell stage to the eight-cell stage and during the progression into the 32-cell stage (Pedersen et al., 1986). During this time, localization of the individual blastomeres permits the distinction of inner and outer blastomeres and this spatial difference is likely to contribute to the observed divergent gene expression (Jedrusik et al., 2008). The Tead(Nishioka et al., 2008; Yagi et al., 2007), Elf5, Cdx2 and Eomes genes (Niwa et al., 2005; Russ et al., 2000; Strumpf et al., 2005) become successively activated in the outer blastomeres and specify their trophoectoderm fate by repressing Oct4, Sox2 and Nanog, which remain expressed in the inner pluripotent blastomeres (Avilion et al., 2003; Chambers, 2004; Chambers et al., 2003; Chambers and Tomlinson, 2009; Mitsui et al., 2003; Nichols et al., 1998; Scholer et al., 1989b; Silva et al., 2009). Accordingly, all Oct4, Sox2, Nanog and Sall4 promoters contain euchromatin marks, i.e. trimethylated $\mathrm{H} 3 \mathrm{~K} 4$, acetylated H4K16 and absence of methyl-cytosine. Although global histone methylation patterns in different blastomeres diverge from each other once the first cell fate decision occurs, all inner blastomeres remain pluripotent, indicating that the lack of polarity predisposes these cells for maintenance of pluripotency up to the ICM stage (Zernicka-Goetz et al., 2009). Sustained Oct4 expression in the inner morula cells causes $C d x 2$ and Tcfcap2 silencing through Oct4 mediated targeting of $\mathrm{H} 3 \mathrm{~K} 9 \mathrm{me} 3$ to the respective genomic loci (Yuan et al., 2009). Most epigenetic alterations during this time target the silencing of differentiation associated genes, and PRC2 associated proteins play a significant role in this process. Their reduction leads to severe growth retardation in neonates, possibly due to dysregulation of the murine $\mathrm{H} 19$ /lgf2 locus (Erhardt et al., 2003a) and impaired Oct4 silencing (Li et al., 2010). In addition, PRC1/2 mediated repression precedes Suv39h silencing during early embryogenesis at selected genomic loci since mouse embryos with reduced levels of the PRC2 associated histone methyltransferase Ezh2/Kmt6 also show reduced levels of the repressive H3K9me3 mark (Erhardt et al., 2003b). Therefore, both Eset/Kmt1e and Ezh2/Kmt6 are essential for derivation of pluripotent stem cells (Dodge et al., 2004; O'Carroll et al., 2001).

Epigenetic reprogramming is completed in the final stages of $\mathrm{PID}$ with $\mathrm{X}$ chromosome inactivation $(\mathrm{XCl})$. $\mathrm{XCl}$ is marked by the interplay of histone modifications, expression of non-coding RNAs, and DNA methylation for transcriptional regulation. $\mathrm{XCl}$ is controlled by $\mathrm{X}$ chromosome elements at the $\mathrm{X}$ inactivation center (Xic). Xic functions both in trans, through transient pairing of the two X chromosomes that marks the onset of XCI (Xu et al., 2006), and in cis through the non-coding RNAs Xite, Tsix, and Xist located within it. Allele-specific upregulation of Xist on the future inactive $\mathrm{X}$ chromosome $(\mathrm{Xi})$ is preceded by the down-regulation of the antisense transcript Tsix and the enhancer-like Xite (Ogawa and Lee, 2003; Stavropoulos et al., 2005). Xist coats the future Xi, 
initiating a cascade of epigenetic events that result in transcriptional silencing of the future $\mathrm{Xi}$ along its entire length. These epigenetic modifications include a set of repressive histone modifications, acquisition of the histone variant macroH2A, and DNA methylation at CpG residues (Lucchesi et al., 2005) and also facilitate the continued maintenance of $\mathrm{Xi}$ silencing in somatic cells. Reactivation of the $\mathrm{Xi}$ in the germ line requires the presence of hitherto unknown reprogramming factors that are also present in the fertilized zygote.

\section{Artificial reprogramming}

Three different methods have been established for the artificial reprogramming of somatic cells (Fig. 3) including somatic cell nuclear transfer (SCNT) into enucleated oocytes, fusion mediated reprogramming (FMR) and transcription factor mediated induction of pluripotency (iPS).

\section{Somatic cell nuclear transfer}

Mature vertebrate oocytes have the ability to reprogram the genetic content of somatic cells to a state of totipotency. SCNT was first demonstrated in Xenopus (Gurdon, 1962). Only after considerable time was SCNT achieved in sheep (Campbell et al., 1996; Wilmut et al., 1997), and then successes were rapidly reported for mice (Wakayama et al., 1998). To date, SCNT remains the only method of artificial reprogramming that is capable of yielding a state of totipotency, as reconstructed embryos produced by this method can develop into mature blastocysts in vitro, which upon implantation yield all extra-embryonic cellular lineages in addition to the embryo proper. The source of biochemical activities that facilitate reprogramming are contained within the ooplasm of mature oocytes that are arrested at Meiosis II (MII), which have been made devoid of genetic material. Because MII oocytes are arrested in meiotic metaphase, they lack nuclear envelopes and their ooplasm is thus a mixture of nucleoplasmic and cytoplasmic components. Following transfer of the somatic nucleus into recipient oocytes, the somatic nucleus rapidly disassembles, and the chromosomes condense and form a disorganized spindle containing a $2 \mathrm{~N}$ complement of somatic chromosomes. Then, upon activation and suppression of polar body extrusions to maintain a diploid content of chromosomes, the reconstructed embryos execute the remainder of preimplantation development much like embryos produced by normal fertilization. Somatic nuclei contain differentiated transcriptional and epigenomic states that are imposed by their somatic cell type. The epigenome and transcriptome states of somatic nuclei are readily undone during the presumably massive reprogramming that occurs shortly after SCNT. By inference, MII ooplasm must therefore contain a highly effective machinery that can establish a state of totipotency upon somatic chromosomes. Since SCNT

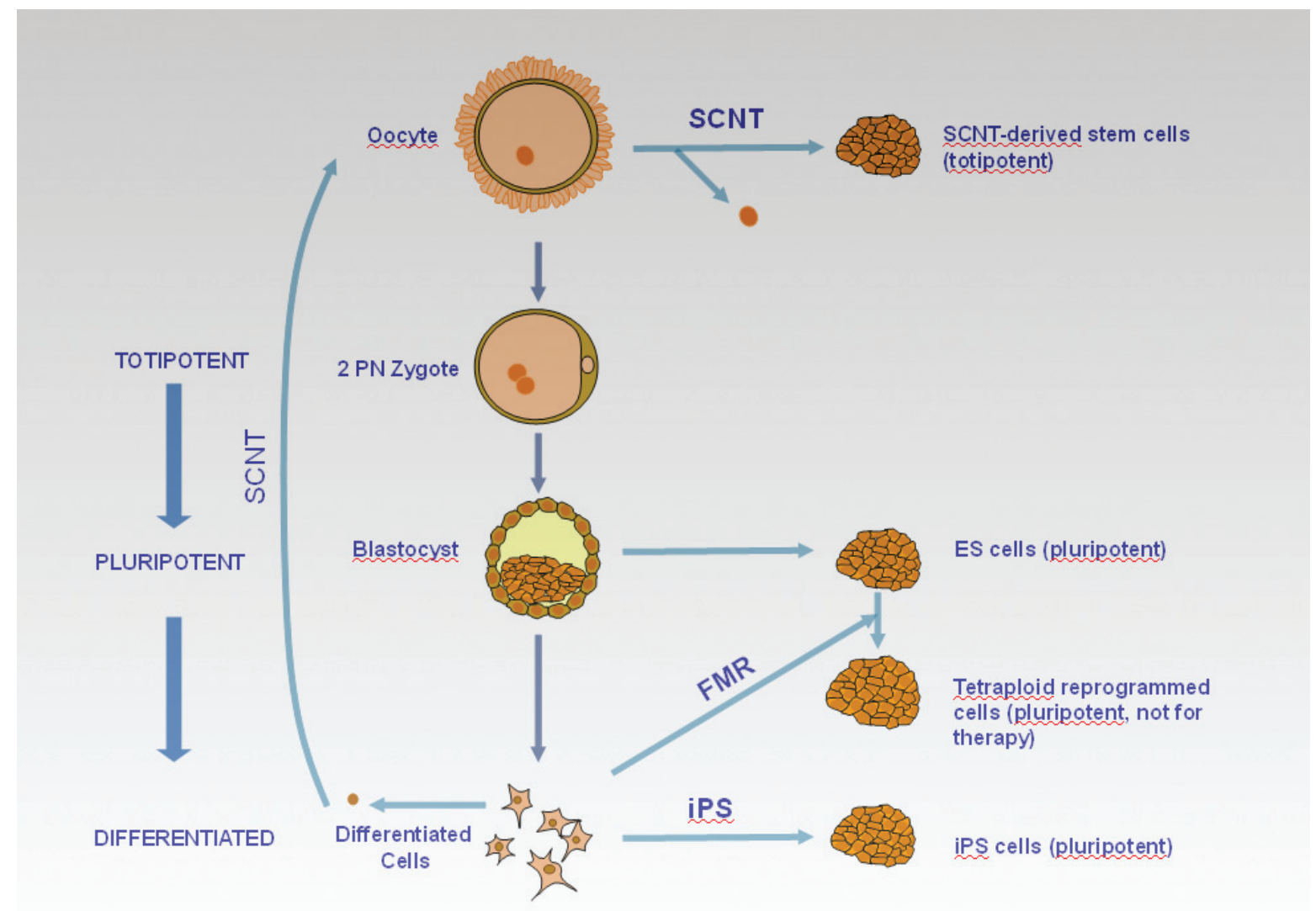

Fig. 3. Routes to pluripotency and their cell sources. The genesis of toti-and pluripotent stem cells is depicted including somatic cell nuclear transfer (SCNT), fusion mediated reprogramming (FMR), generation of induced pluripotent stem cells (iPS), inner cell mass cell explants (ES cells) and blastocysts formation. Cell nuclei and oocyte pro-nuclei are drawn in solid brown. Please note that for SCNT the oocyte pronucleus is removed prior to injection of the somatic nucleus. 
occurs within single cells, the paucity of material in this system makes cell biological investigations especially attractive. One of the most established epigenetic features of normal female diploid somatic cells is $X$ chromosome inactivation. Analysis of the inactive $X$ chromosome during SCNT reveals that $X$ chromosome inactivation can be reversed during this process in the embryo proper. However, the inactive $X$ chromosome of somatic cell origin is retained in a uni-parental imprinted-like state in trophectodermal lineages of SCNT embryos (Eggan et al., 2000). $X$ chromosome inactivation, and even maintenance of proper ploidy, is less stringent in SCNT embryos as compared to normal embryos (Nolen et al., 2005), a finding that is in agreement with greatly reduced rates of development to term of SCNT embryos as compared to normal fetal development. The extent to which reduced rates of fetal development can be attributed to faults in epigenetic reprogramming cannot easily be ascertained, but analyses of $X$ inactivation suggest that incomplete epigenetic reprogramming plays a major role.

A number of studies show that the degree and fidelity of epigenetic reprogramming is variable in SCNT. Indeed, many studies indicate the partial or improper epigenetic reprogramming is associated with developmental failure of SCNT embryos. For instance, expression of imprinted genes is abnormal in most blastocysts created by SCNT (Mann et al., 2003). Some of the failures in reprogramming during SCNT can be attributed to epigenetic memory of somatic cell transcription states, as in the case of the endoderm-specific endodermin (edd) or the mesoderm specific MyoD genes which continue to be transcribed when endoderm and mesoderm cells, respectively, are used as nuclear donors. The MyoD gene is transcribed in reconstructed embryos for many cell divisions, and the MyoD promoter remains associated with histone $\mathrm{H} 3.3$, a variant that is incorporated into actively transcribed genes ( $\mathrm{Ng}$ and Gurdon, 2008b). Epigenetic memory of somatic chromatin states has also been reported in bovine SCNT embryos, which retain H3K9me marks and DNA CpG methylation marks that resemble those of the somatic cell donor type (Santos et al., 2003). Developmentally regulated genes (including Hox genes) are precociously marked in ES cells and ICM cells by bivalent domains, consisting of the combined occurrence of $\mathrm{H} 3 \mathrm{~K} 4 \mathrm{me} 3$ and $\mathrm{H} 3 \mathrm{~K} 27 \mathrm{me} 3$. Bivalent domains are later resolved during ensuing development, where they retain only H3K4me3 (if expressed) and H3K27 only (if silenced) (reviewed in (Rasmussen, 2008)). However, in SCNT embryos, bivalent domains are perturbed, and SCNT embryos in general have higher expression of bivalent genes. Furthermore, this effect is associated with mis-regulated levels of PRC2, a finding that suggests that failed bivalent domain epigenetic regulation may be a key cause for post-implantation failure of SCNT embryos (Esteban et al., 2010). In general, many blastocysts are produced during in vitro development of SCNT embryos to the blastocyst stage. However, after implantation and subsequent embryogenesis in vivo, a high proportion of SCNT embryos die, probably because it is the rare SCNT embryo that has been sufficiently reprogrammed to develop to term.

\section{ES cell fusion-mediated reprogramming (FMR)}

Embryonic germ (EG) cells are derived from primordial germ cells (PGCs) and can reprogram somatic cells on an epigenetic level when EG cells are fused to somatic cells such as thymic lymphocytes (Tada et al., 1997). In such EG/somatic hybrids, demethylation of imprinted genes was observed, resulting in a hypomethylated state of the normally imprinted Peg1/Mest gene in the hybrids, a state normally observed only in germ cells. Subsequently, it was found that ES cells also harbor activities that can reprogram the somatic genome to a state of pluripotency upon fusion (Tada et al., 2003). The resulting hybrid lines, though roughly tetraploid, exhibit pluripotency reminiscent of ES cells. Successful reprogramming results were also obtained by fusing human ES cells with human fibroblasts (Cowan et al., 2005). In another study, the transcriptome of mouse ES cell/fibroblast hybrid lines was found to be very similar to normal ES cells and the use of expressed polymorphisms confirmed that genes residing on chromosomes of fibroblast origin assumed a transcriptional state resembling that of ES cells (Ambrosi et al., 2007). Interestingly, the reprogramming activities within ES cells are confined to the nucleus since karyoplasts, but not cytoplasts, can achieve FMR (Do and Scholer, 2004). The above studies show that ES/somatic cell hybrid cell lines are pluripotent, and have gene expression states similar to normal ES cells. FMR occurs quickly as compared to iPS, being essentially complete after only one cell cycle, with demethylation of Oct4 proximal enhancer element (Han et al., 2008a). Methylation analyses of pluripotency genes have also been conducted in hybrid cells produced by fusion of Mus musculus ES cells and Mus caroli splenocytes. In these hybrid cells, CpG sites near Oct4 and Nanog on the caroli supplied chromosomes became substantially demethylated in the reprogrammed hybrids (Battulin et al., 2009). The mechanism responsible for FMR also involves the ability of cells to remodel their histone modification content. In a recent study, using fluorescent reporters to indicate fusion and the establishment of pluripotency, it was found that knockdown of histone methyltransferase G9a promoted reprogramming. Furthermore, overexpression of the histone demethylase Jhdm2a causes increased reprogramming effectiveness as judged by Oct4 promoter-driven GFP expression (Ma et al., 2008). Together, the results indicate that FMR is associated with changes in the modification states of histones, and decreased CpG cytosine methylation near promoters of key pluripotency genes.

Activation of the inactive $X$ chromosome has also been reported in the experiments that employ reprogramming mediated by fusion of female somatic cells with pluripotent counterparts. Initial attempts to reprogram somatic $\mathrm{Xi}$ in female fibroblasts by fusion with murine teratocarcinoma stem cell lines failed (Graves and Young, 1982). Further fusion attempts of murine embryonal carcinoma (EC) cells with female lymphocytes led to the classification of EC cells into two groups, one with and one without the potential to reactivate the $\mathrm{Xi}$ of the somatic origin in EC-like hybrids (Mise et al., 1996). These results most likely reflect the developmental stages from which these EC cells have been derived, as certain EC-like hybrids show complete reactivation of $\mathrm{X}$ chromosomes, with subsequent random $\mathrm{XCl}$ of any three out of four X chromosomes present in fusion cells (Takagi, 1993). On the other hand, fusion experiments in which ESCs were used as fusion partner that will bring about reprogramming capabilities, show more consistent and complete reactivation of the Xi from the somatic partner. Hybrids created by fusion of male murine ESCs with female mouse splenocytes showed presence of synchronously replicating $\mathrm{X}$ chromosomes, as judged by BrdU incorpora- 
tion, followed by colchicine treatment and Giemsa staining (Matveeva et al., 1998). Synchronously and early replicating $X$ chromosomes have also been observed in the fusions between male ESCs and adult thymocytes (Tada et al., 2001). This report further showed punctuate Xist RNA-FISH signal on three $X$ chromosomes present in hybrid cells, indicative of all three $\mathrm{X}$ chromosomes being in pre-inactivation state.

\section{iPS - Conceptual basis for factor based reprogramming}

Reprogramming of the somatic genome to a state of pluripotency by introduction of defined factors has recently been reported (Takahashi and Yamanaka, 2006; Yu et al., 2007.). The success of iPS, which can be initiated by only four (or fewer) factors, shows that terminally differentiated cells have the capacity to reorganize their epigenomes dramatically, if only the correct cues are given. Conceptually, these cues represent the key mediators of epigenetic remodeling and a set of master transcription factors active during natural reprogramming in PID. In addition, a series of molecular events resembling those in gametogenic prepatterning may also need to occur. This may require the expression of additional effectors expressed during gametogenesis for high efficiency artificial reprogramming.

\section{Methods for generation of induced pluripotent stem cells}

Historically, iPS cells have been generated by introduction of either Oct4, Sox2, KIf4 and c-myc or Oct4, Sox2, Nanog and Lin28 into somatic cells (Takahashi and Yamanaka, 2006; Yu et al., 2007). Currently, numerous approaches are available for the reprogramming of somatic cells ranging from introduction of additional factors to numerous viral and nonviral gene transfer strategies. Other variations include choice of somatic cells, the levels and time course of factor expression, culture conditions, and methods to identify bona fide iPS cells and to some extent these protocols reflect the method chosen for factor delivery (Takahashi et al., 2007; Maherali and Hochedlinger, 2008).

Most technical alterations target disadvantages inherent to retroviral gene transfer methods since retroviruses only infect dividing cells, integrate into the host genome thereby giving rise to genomic mutations and tend to be gradually silenced even if reprogramming is incomplete. The latter is of particular concern since transgene silencing differs from cell type to cell type and is most efficient in ES cells (Ma et al., 2003). Moreover, reactivation of the transgenes could also be observed (Maherali et al., 2008). Lentiviruses escape many of these issues and have been used successfully for the derivation of iPS cells (Yu et al., 2007). One significant modification in the use of lentiviral vectors consists in the use of a doxycycline-inducible construct, permitting precise control over transgene expression
(Fig. 4) (Brambrink et al., 2008; Stadtfeld et al., 2008; Wernig et al., 2008). More recently, doxycycline-controlled lentiviral delivery systems have been generated in which the reprogramming factors are expressed from a single cistron linked through multiple $2 \mathrm{~A}$ ribosome skipping sequences (Shao et al., 2009). A significant effort has been expended to omit viral integration by the use of loxP sites introduced into the viral LTRs for near complete removal of the viral cassette through expression of Crerecombinase (Soldner et al., 2009). Alternatively, single cistron expression cassettes encoding the four reprogramming factors have been delivered into cells through piggyBac transposons which avoid any remaining integration through expression of transposase or Cre-recombinase (Kaji et al., 2009; Woltjen et al., 2009). Finally, adenovirus based vectors with inherent low integration frequencies have also successfully been used for iPS from both mouse and human fibroblasts (Stadtfeld et al., 2008; Zhou and Freed, 2009). Unfortunately, adenoviral based gene expression suffers from low infectivity and reprogramming rates as low as of $0.0002 \%$ in man, even if much higher amounts of virus and multiple rounds of infection are employed (Stadtfeld et al., 2008; Zhou and Freed, 2009).

Cell membrane penetrating protein technology has also been utilized successfully for the introduction reprogramming factors into somatic cells using C-terminal fusions selected reprogramming factor, the TAT protein transduction domain and a nuclear localization signal (Bosnali and Edenhofer, 2008). Alternatively,

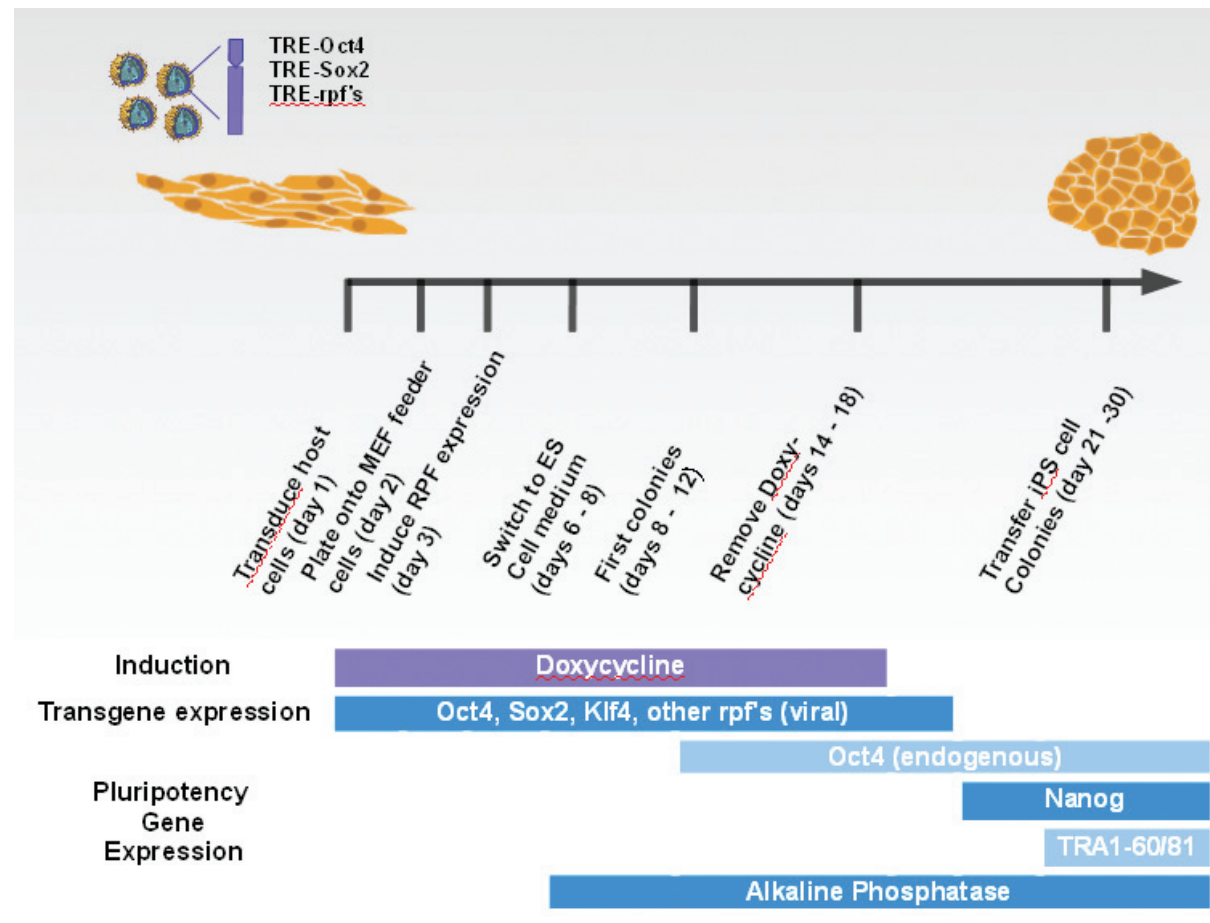

Fig. 4. Generation of induced pluripotent stem (iPS) cells by lentiviral introduction of reprogramming factors using a doxycycline inducible expression system (Maherali et al., 2008). The time course for expression of both exogenous and endogenous proteins associated with pluripotency is depicted. Please note that the depicted doxycycline induction time course reflects the use of normal dermal skin fibroblasts from healthy individuals and may need adjusting if other cell sources are employed. Abbreviations: TRE (tetracycline response element), rpf's (reprogramming factors). 
substitution of TAT sequence with oligo-arginine has also been reported (Yang et al., 2009) but either approach has yet to demonstrate efficiency in producing iPSCs. In a variation of this approach, mouse ES cell extracts were introduced into streptolysin O-mediated reversible permeabilized cells and bona fide iPS cells were successfully derived (Cho et al., 2010; Collas and Taranger, 2006).

Finally, small molecules have also been employed for reprogramming with various success, but no iPS cell lines have been created yet using this approach alone (Maherali and Hochedlinger, 2008). However, supplementation of reprogramming factors and even substitution of individual factors with small molecules has been demonstrated to drastically increase the efficiency of reprogramming. Components used include HDAC inhibitors such as valproic acid, suberoylanilide hydroxamic acid and trichostatin $A$, DNA methyltransferase inhibitors such as 5'-azacytidine (5'azaC) and RG108, histone methyltransferase inhibitors such as BIX01294 and Ca-channel activators such as R(+)Bay K 8644 (Huangfu et al., 2008a; Maherali et al., 2008; Shi et al., 2008). Addition of valproic acid, which is also beneficial in SCNT (Huangfu et al., 2008a), increased reprogramming efficiency 100-fold and allowed for successful reprogramming to occur without the addition of factors KIf4 and c-myc, two known oncogenes (Huangfu et al., 2008b). Intriguingly, partially reprogrammed cells obtained during reprogramming show significant hypermethylation of important pluripotency-related genes and addition of 5'-aza-cytidine ameliorated hypermethylation without affecting the silencing of the viral transgenes (Huangfu et al., 2008a; Mikkelsen et al., 2008), albeit high levels of cell death were observed (Mikkelsen et al., 2008).

Remarkably, choice of somatic cell equally affects reprogramming efficiency. Both diminished proliferative and increased senescent status affect reprogramming rates negatively (Banito et al., 2009). In addition, continued passaging in vitro also decreases reprogramming rates (Maherali and Hochedlinger, 2008; Utikal et al., 2009) due to an increase in uncontrolled somatic cell DNA damage. Subsequent increase in p53 activity induces apoptosis upon viral entry and prevents reprogramming (Marion et al., 2009). Consistent with this observation, p53 deficient cells can be fully reprogrammed despite DNA damage (Marion et al., 2009; Utikal et al., 2009) and several approaches have been employed that affect the p53 signaling pathway including p53knock down (Hong et al., 2009; Kawamura et al., 2009; Marion et al., 2009; Utikal et al., 2009), p21 knockdown and Ink4/Arf inactivation (Banito et al., 2009; Hanna et al., 2009; Hong et al., 2009; Kawamura et al., 2009; Li et al., 2009).

\section{Reprogramming mechanism and defects}

The epigenetic mechanism underlying factor based artificial somatic reprogramming remains largely enigmatic. The emerging variety of reprogramming strategies suggests that artificial reprogramming occurs in a random sequence of chromatin modifying events in all cells expressing the entire set of reprogramming factors. A viable order of events occurs only in a few random cells and successfully yields ESC-like cells (Yamanaka, 2009). This stochastic model contrasts the less likely hypothesis that successful reprogramming occurs only in cells that preexist in a reprogramming permissive state and employs an orchestrated sequence of events akin those during natural reprogramming in the germ line and PID (elite model). However, similarities between a zygote and pluripotency factor expressing somatic cells exist and certain elements of the natural reprogramming are recapitulated during the production of induced pluripotent stem cells including the upregulation of the Oct4, Sox2 and Nanog dependent pluripotency network. It should be noted in this context that artificial upregulation of Oct4 and Sox2 alone is sufficient for induction of Nanog, obviating the addition of exogenous Nanog (Jaenisch and Young, 2008).

In comparison to Oct4 and Sox2, KIf4 and c-Myc appear to exert less specific and more pleiotropic functions. For instance, the somatic chromatin is far less dynamic than its pluripotent counterpart (Meshorer et al., 2006) and is likely to obstruct access for Oct4 and Sox 2 to their native genes. C-myc may function as a general transcriptional activator and chromatinopener (Knoepfler et al., 2006) given its association with p300, CREBP and TRRAP, all components of histone acetyltransferase complexes including STAGA and TIP60 (Faiola et al., 2005; Liu et al., 2008; Park et al., 2001; Vervoorts et al., 2003). More specifically, c-Myc may also be required for activation of one of its target genes encoding telomerase reverse transcriptase required for sustained proliferation of iPS cells (Liu et al., 2008). Indeed, inclusion of TERT into the reprogramming mix is associated with increased reprogramming efficiencies (Park et al., 2008). Further targets include the cell-cycle associated genes p15, p21 and cyclin E. Together with c-Myc induced enhanced replication dependent DNA-synthesis, their regulation may precipitate the cell cycle shortening observed in pluripotent stem cells (Egli et al., 2008), aiding in the increased frequency of opportunities for epigenetic reprogramming (Scheper and Copray, 2009). Intriguingly, Oct4 and Sox2 are only able to activate the ES-cell specific gene LEFTY1 in the presence of KIf4 (Nakatake et al., 2006). In addition to aiding Oct4 and Sox2 in gene activation, Klf4 inhibits p53 which may be important for activation of the Nanog gene in senescent cells (Lin et al., 2005; Rowland et al., 2005).

Consistent with the comprehensive effects of the core reprogramming factor mix, a number of additional factors have been identified that are capable of either substituting KIf4 or c-myc or further supplement this quartet. Prominent examples for these proteins are Lin28 (Viswanathan et al., 2008), Esrrb (Feng et al., 2009) or Sall4 (Yang et al., 2008). Lin28 interferes with differentiation through RNA stabilization, Esrrb mediates a key pathway downstream of the master pluripotency regulators and Sall4 affects the regulation of Oct4 directly (Zhang et al., 2006).

During the generation of iPS cells, both incompletely and fully reprogrammed cells are obtained, but fully reprogrammed pluripotent stem cells appear at much lower frequencies than in SCNT or FMR, likely owing to the inability to control expression levels during induced expression of reprogramming factors. For instance, both expression of Oct4 below and above a predetermined threshold are known to induce differentiation into either trophoectoderm and primitive endoderm or mesoderm, respectively (Gidekel et al., 2003; Niwa et al., 2000; Zaehres et al., 2005). Similarly, imbalance of Klf4 and c-Myc expression affects reprogramming integrity significantly, since KIf4 is thought to balance c-Myc via control of p21 activity (Rowland and Peeper, 2006; Yamanaka, 2007). The effect of factor imbalance is exemplified by employing direct transfection of repro- 
gramming factor, encoding modified RNAs in defined amounts which increases iPS efficiency almost 100 fold (Warren et al., 2010). Further interdependencies including the senescent state and genomic integrity of the target cells are just beginning to emerge (Banito et al., 2009). Consistent with the complexity and probabilistic nature of artificial reprogramming, most of the colony-forming cells demonstrate a partial reprogrammed phenotype as judged by above criteria and only a small number genuine iPS cells remain.

Consistent with the low frequency for bona fide iPS cells is the scarcity with which viable transgenic adult mice can be generated through either chimera formation or tetraploid complementation (Boland et al., 2009; Zhao et al., 2009). Furthermore, recent reports employing in depth molecular analyses suggest that the successful generation of iPS cells as measured by morphological criteria, molecular marker expression (Tra1-60/ 1-81, SSEA1/mouse, SSEA3/human, Nanog and Oct4 (Brambrink et al., 2008)), promoter methylation status and the ability to give rise to numerous types of differentiated progeny during teratoma formation, may overestimate the number of bona fide iPS cells generated. For instance, the typically performed analysis of DNA methylation patterns for the Oct4 and Nanog promoters reveals small but detectable differences between ES cells and iPS cells (Maherali et al., 2007; Okita et al., 2007; Smith et al., 2009; Takahashi and Yamanaka, 2006; Wernig et al., 2007), indicating a sometimes minute change in the overall density of methylation marks (Boyes and Bird, 1992; Hanna et al., 2008; Smith et al., 2009). This might affect endogenously produced Oct4 levels and the extent of downstream reprogramming since Oct4 levels are greatly tuned for maintenance of pluripotency (Niwa et al., 2000). Examples illustrating the effect of near-miss of complete reprogramming include similarity but not identity in ESCs and iPS cells of 3'UTR length (Ji and Tian, 2009), heightened promoter occupancy in target genes for Oct4, Sox2 and Nanog (Huang et al., 2009) and differences in the DNA methylomes (Doi et al., 2009; Pick et al., 2009). Differences in 3'UTR length through the use of alternative polyadenylation sites may affect the presence of cisregulatory elements for mRNA stability and/or translatability ( $\mathrm{Ji}$ and Tian, 2009) and lead to post-transcriptional changes in the proteome of iPSC compared to ESCs. A more than 10-fold increased promoter occupancy observed in high fidelity iPSCs as judged by traditional assays, affects four signaling pathways specifically in iPSCs (Huang et al., 2009) and further investigation is needed to determine its significance in the context of pluripotency. The differences in the DNA-methylomes of human iPS cells compared to ES cells are significant and affect both imprinted genes (Pick et al., 2009) and loci encoding gene products essential to developmental processes (Doi et al., 2009). These included the DIk1-Dio3 gene cluster in mice, which contains maternally expressed genes, Gt/2, Rian and Mirg, and the paternally expressed genes, DIk1 and Dio3 (Stadtfeld et al., 2010), and region p15 on chromosome 11 in man, containing the H19, IGF2, and KCNQ10T1 genes implicated in hyperplasia and Beckwith-Wiedemann syndrome (Pick et al., 2009). Finally, other observed DNA methylation divergences consisted of 71 loci showing differential DNA-methylation in iPS cells compared to ES cells and nearly half of these were located near genes such as HOXA9, ZBF568, ZFP112,
PTPRT (a multi-functional tyrosine phosphatase) and TBX5, a transcription factor essential for cardiac and limb development (Doi et al., 2009). Notably, imprinting defects appear to be associated with increasing passage numbers of the source cells used for reprogramming (Pick et al., 2009), but no data exist for DNA methylation divergences among other loci.

\section{Summary and outlook}

Both natural and artificial routes to pluripotency depend on the master pluripotency factors Oct4, Sox 2 and Nanog and also share molecular features such as restructuring of the nuclear organization. Both routes employ a biphasic mechanism: During gametogenesis concerted chromatin remodeling occurs, predisposing it to pluripotency. Upon fertilization, Oct4, Sox2 and Nanog expression is induced, resulting in the activation of the downstream pluripotency transcription network. Similarly, ectopic expression of Oct4, Sox2 and Nanog may produce a pseudozygotic state during artificial reprogramming but conversely, this state is devoid of chromatin poised for pluripotency. Forced prolonged expression of Oct4, Sox2 and Nanog is necessary for somatic cells to enter the pluripotent state and it is likely that the orchestrated events during gametogenesis that yield the chromatin poised for pluripotency occur now in a stochastic fashion. Moreover, the start of chromatin remodeling occurs in an inverse order with respect to the cellular presence of Oct4, Sox2 and Nanog. An implication might be that chromatin modifiers that are active during gametogenesis may also function as additional reprogramming factors during iPS, perhaps improving efficiency and/ or fidelity.

The stochastic mechanism during artificial reprogramming is consistent with the observed inefficiency of artificial reprogramming and the realization that increasing numbers of previously deemed bona fide iPS cells reside in an aberrant epigenetic state due to the partial retention of somatic chromatin that is initially dispensable for pluripotency. In utero, gametocyte fitness and embryo survival is dependent on appropriate chromatin remodeling, providing a stringent quality control mechanism. In vitro, no such mechanism exists and current criteria may prove to be inadequate for the certification of clinical grade iPSCs. Novel culture conditions and tests capable of scanning for molecular variance between ES cells and iPS cells at high resolution may all be required to resolve these issues.

\section{References}

ADENOT, P.G., MERCIER, Y., RENARD, J.P. and THOMPSON, E.M. (1997) Differential $\mathrm{H} 4$ acetylation of paternal and maternal chromatin precedes DNA replication and differential transcriptional activity in pronuclei of 1-cell mouse embryos. Development 124: 4615-4625.

AFLATOONIAN, B., RUBAN, L., JONES, M., AFLATOONIAN, R., FAZELI, A. and MOORE, H.D. (2009). In vitro post-meiotic germ cell development from human embryonic stem cells. Hum Reprod 24: 3150-3159.

AHMAD, K. and HENIKOFF, S. (2002). The histone variant H3.3 marks active chromatin by replication-independent nucleosome assembly. Mol Cell 9: 1191 1200.

AMBROSI, D.J., TANASIJEVIC, B., KAUR, A., OBERGFELL, C., O'NEILL, R.J., KRUEGER, W. and RASMUSSEN, T.P. (2007). Genome-wide reprogramming in hybrids of somatic cells and embryonic stem cells. Stem Cells 25: 1104-1113.

ANCELIN, K., LANGE, U.C., HAJKOVA, P., SCHNEIDER, R., BANNISTER, A.J., 
KOUZARIDES, T. and SURANI, M.A. (2006). Blimp1 associates with Prmt5 and directs histone arginine methylation in mouse germ cells. Nat Cell Biol 8: 623630.

ANDRES, V. and GONZALEZ, J.M. (2009). Role of A-type lamins in signaling, transcription, and chromatin organization. J Cell Biol 187: 945-957.

AOKI, F., WORRAD, D.M. and SCHULTZ, R.M. (1997). Regulation of transcriptional activity during the first and second cell cycles in the preimplantation mouse embryo. Dev Biol 181: 296-307.

AVILION, A.A., NICOLIS, S.K., PEVNY, L.H., PEREZ, L., VIVIAN, N. and LOVELLBADGE, R. (2003). Multipotent cell lineages in early mouse development depend on SOX2 function. Genes Dev 17: 126-140.

BALHORN, R., REED, S. and TANPHAICHITR, N. (1988). Aberrant protamine 1/ protamine 2 ratios in sperm of infertile human males. Experientia 44: 52-55.

BANITO, A., RASHID, S.T., ACOSTA, J.C., LI, S., PEREIRA, C.F., GETI, I., PINHO, S., SILVA, J.C., AZUARA, V., WALSH, M. et al. (2009). Senescence impairs successful reprogramming to pluripotent stem cells. Genes Dev23: 2134-2139.

BATTULIN, N.R., PRISTYAZHNYUK, I.E., MATVEEVA, N.M., FISHMAN, V.S., VASILKOVA, A.A. and SEROV, O.L. (2009). Allelic expression and DNA methylation profiles of promoters at the parental Oct4 and Nanog genes in Mus musculus ES cell/Mus caroli splenocyte hybrid cells. Cell Tissue Res 337: 439448.

BERNSTEIN, B.E., HUMPHREY, E.L., ERLICH, R.L., SCHNEIDER, R., BOUMAN, P., LIU, J.S., KOUZARIDES, T. and SCHREIBER, S.L. (2002). Methylation of histone H3 Lys 4 in coding regions of active genes. Proc Natl Acad Sci USA 99: 8695-8700.

BERNSTEIN, B.E., MIKKELSEN, T.S., XIE, X., KAMAL, M., HUEBERT, D.J., CUFF, J., FRY, B., MEISSNER, A., WERNIG, M., PLATH, K. et al. (2006). A bivalent chromatin structure marks key developmental genes in embryonic stem cells. Cell 125: 315-326.

BOLAND, M.J., HAZEN, J.L., NAZOR, K.L., RODRIGUEZ, A.R., GIFFORD, W., MARTIN, G., KUPRIYANOV, S. and BALDWIN, K.K. (2009). Adult mice generated from induced pluripotent stem cells. Nature 461: 91-94.

BOSNALI, M. and EDENHOFER, F. (2008). Generation of transducible versions of transcription factors Oct4 and Sox2. Biol Chem 389: 851-861.

BOURC'HIS, D. and BESTOR, T.H. (2004). Meiotic catastrophe and retrotransposon reactivation in male germ cells lacking Dnmt3L. Nature 431: 96-99.

BOURC'HIS, D., XU, G.L., LIN, C.S., BOLLMAN, B. and BESTOR, T.H. (2001). Dnmt3L and the establishment of maternal genomic imprints. Science 294: 2536-2539.

BOYER, L.A., LEE, T.I., COLE, M.F., JOHNSTONE, S.E., LEVINE, S.S., ZUCKER, J.P., GUENTHER, M.G., KUMAR, R.M., MURRAY, H.L., JENNER, R.G. et al (2005). Core transcriptional regulatory circuitry in human embryonic stem cells. Cell 122: 947-956.

BOYES, J. and BIRD, A. (1992). Repression of genes by DNA methylation depends on $\mathrm{CpG}$ density and promoter strength: evidence for involvement of a methylCpG binding protein. EMBO J 11: 327-333.

BRAMBRINK, T., FOREMAN, R., WELSTEAD, G.G., LENGNER, C.J., WERNIG, M., SUH, H. and JAENISCH, R. (2008). Sequential expression of pluripotency markers during direct reprogramming of mouse somatic cells. Cell Stem Cell 2: 151-159.

BROOKES, E. and POMBO, A. (2009). Modifications of RNA polymerase II are pivotal in regulating gene expression states. EMBO Rep 10: 1213-1219.

BURATOWSKI, S. (2009). Progression through the RNA polymerase II CTD cycle. Mol Cell 36: 541-546.

BUSCHBECK, M., URIBESALGO, I., WIBOWO, I., RUE, P., MARTIN, D., GUTIERREZ, A., MOREY, L., GUIGO, R., LOPEZ-SCHIER, H. and DI CROCE, $L$. (2009). The histone variant macroH2A is an epigenetic regulator of key developmental genes. Nat Struct Mol Biol 16: 1074-1079.

CAMPBELL, K.H., MCWHIR, J., RITCHIE, W.A. and WILMUT, I. (1996). Sheep cloned by nuclear transfer from a cultured cell line. Nature 380: 64-66.

CARLONE, D.L., LEE, J.H., YOUNG, S.R., DOBROTA, E., BUTLER, J.S., RUIZ, J. and SKALNIK, D.G. (2005). Reduced genomic cytosine methylation and defective cellular differentiation in embryonic stem cells lacking $\mathrm{CpG}$ binding protein. Mol Cell Biol 25: 4881-4891.

CARRELL, D.T. and HAMMOUD, S.S. (2010). The human sperm epigenome and its potential role in embryonic development. Mol Hum Reprod 16: 37-47.

CHAMBERS, I. (2004). The molecular basis of pluripotency in mouse embryonic stem cells. Cloning Stem Cells 6: 386-391.

CHAMBERS, I., COLBY, D., ROBERTSON, M., NICHOLS, J., LEE, S., TWEEDIE, S. and SMITH, A. (2003). Functional expression cloning of Nanog, a pluripotency sustaining factor in embryonic stem cells. Cell 113: 643-655.

CHAMBERS, I., SILVA, J., COLBY, D., NICHOLS, J., NIJMEIJER, B., ROBERTSON, M., VRANA, J., JONES, K., GROTEWOLD, L. and SMITH, A. (2007). Nanog safeguards pluripotency and mediates germline development. Nature 450: 1230-1234.

CHAMBERS, I. and TOMLINSON, S.R. (2009). The transcriptional foundation of pluripotency. Development 136: 2311-2322.

CHANG, C.C., MA, Y., JACOBS, S., TIAN, X.C., YANG, X. and RASMUSSEN, T.P. (2005). A maternal store of macroH2A is removed from pronuclei prior to onset of somatic macroH2A expression in preimplantation embryos. Dev Biol 278 : 367-380.

CHAVEZ, L., BAIS, A.S., VINGRON, M., LEHRACH, H., ADJAYE, J. and HERWIG, R. (2009). In silico identification of a core regulatory network of OCT4 in human embryonic stem cells using an integrated approach. BMC Genomics 10: 314.

CHEN, Z.X. and RIGGS, A.D. (2005). Maintenance and regulation of DNA methylation patterns in mammals. Biochem Cell Biol 83: 438-448.

CHO, H.J., LEE, C.S., KWON, Y.W., PAEK, J.S., LEE, S.H., HUR, J., LEE, E.J., $\mathrm{ROH}$, T.Y., CHU, I.S., LEEM, S.H. et al. (2010). Induction of pluripotent stem cells from adult somatic cells by protein-based reprogramming without genetic manipulation. Blood 116: 386-395.

CHOI, Y., QIN, Y., BERGER, M.F., BALLOW, D.J., BULYK, M.L. and RAJKOVIC, A. (2007). Microarray analyses of newborn mouse ovaries lacking Nobox. Biol Reprod 77: 312-319.

CHOW, C.M., GEORGIOU, A., SZUTORISZ, H., MAIA E SILVA, A., POMBO, A., BARAHONA, I., DARGELOS, E., CANZONETTA, C. and DILLON, N. (2005). Variant histone $\mathrm{H} 3.3$ marks promoters of transcriptionally active genes during mammalian cell division. EMBO Rep 6: 354-360.

CIRIO, M.C., MARTEL, J., MANN, M., TOPPINGS, M., BARTOLOMEI, M. TRASLER, J. and CHAILLET, J.R. (2008). DNA methyltransferase 10 functions during preimplantation development to preclude a profound level of epigenetic variation. Dev Biol 324: 139-150.

CLARKE, H.J., BUSTIN, M. and OBLIN, C. (1997). Chromatin modifications during oogenesis in the mouse: removal of somatic subtypes of histone $\mathrm{H} 1$ from oocyte chromatin occurs post-natally through a post-transcriptional mechanism. J Cell Sci 110 (Pt 4): 477-487.

COLLAS, P. and TARANGER, C.K. (2006). Epigenetic reprogramming of nuclei using cell extracts. Stem Cell Rev 2: 309-317.

CONSTANTINESCU, D., GRAY, H.L., SAMMAK, P.J., SCHATTEN, G.P. and CSOKA, A.B. (2006). Lamin A/C expression is a marker of mouse and human embryonic stem cell differentiation. Stem Cells 24: 177-185.

CORZETT, M., MAZRIMAS, J. and BALHORN, R. (2002). Protamine 1: protamine 2 stoichiometry in the sperm of eutherian mammals. Mol Reprod Dev 61: 519 527.

COWAN, C.A., ATIENZA, J., MELTON, D.A. and EGGAN, K. (2005). Nuclear reprogramming of somatic cells after fusion with human embryonic stem cells. Science 309: 1369-1373.

CREYGHTON, M.P., MARKOULAKI, S., LEVINE, S.S., HANNA, J., LODATO M.A., SHA, K., YOUNG, R.A., JAENISCH, R. and BOYER, L.A. (2008). H2AZ is enriched at polycomb complex target genes in ES cells and is necessary for lineage commitment. Cell 135: 649-661.

DAUJAT, S., WEISS, T., MOHN, F., LANGE, U.C., ZIEGLER-BIRLING, C., ZEISSLER, U., LAPPE, M., SCHUBELER, D., TORRES-PADILLA, M.E. and SCHNEIDER, R. (2009). H3K64 trimethylation marks heterochromatin and is dynamically remodeled during developmental reprogramming. Nat Struct Mol Biol 16: 777-781.

DAVIS, T.L., YANG, G.J., MCCARREY, J.R. and BARTOLOMEI, M.S. (2000). The $\mathrm{H} 19$ methylation imprint is erased and re-established differentially on the parental alleles during male germ cell development. Hum Mol Genet 9: 28852894.

DE LA FUENTE, R., VIVEIROS, M.M., BURNS, K.H., ADASHI, E.Y., MATZUK, M.M. and EPPIG, J.J. (2004). Major chromatin remodeling in the germinal 
vesicle (GV) of mammalian oocytes is dispensable for global transcriptional silencing but required for centromeric heterochromatin function. Dev Biol 275: 447-458.

DEBEY, P., SZOLLOSI, M.S., SZOLLOSI, D., VAUTIER, D., GIROUSSE, A. and BESOMBES, D. (1993). Competent mouse oocytes isolated from antral follicles exhibit different chromatin organization and follow different maturation dynamics. Mol Reprod Dev 36: 59-74.

DELAVAL, K. and FEIL, R. (2004). Epigenetic regulation of mammalian genomic imprinting. Curr Opin Genet Dev 14: 188-195.

DELAVAL, K., GOVIN, J., CERQUEIRA, F., ROUSSEAUX, S., KHOCHBIN, S. and FEIL, R. (2007). Differential histone modifications mark mouse imprinting control regions during spermatogenesis. EMBO J 26: 720-729.

DEPA-MARTYNOW, M., KEMPISTY, B., LIANERI, M., JAGODZINSKI, P.P. and JEDRZEJCZAK, P. (2007). Association between fertilin beta, protamines 1 and 2 and spermatid-specific linker histone $\mathrm{H} 1$-like protein mRNA levels, fertilization ability of human spermatozoa, and quality of preimplantation embryos. Folia Histochem Cytobiol 45 Suppl 1: S79-85.

DILLON, S.C., ZHANG, X., TRIEVEL, R.C. and CHENG, X. (2005). The SETdomain protein superfamily: protein lysine methyltransferases. Genome Biol6: 227.

DO, J.T. and SCHOLER, H.R. (2004). Nuclei of embryonic stem cells reprogram somatic cells. Stem Cells 22: 941-949.

DODGE, J.E., KANG, Y.K., BEPPU, H., LEI, H. and LI, E. (2004). Histone H3-K9 methyltransferase ESET is essential for early development. Mol Cell Biol 24: 2478-2486.

DOI, A., PARK, I.H., WEN, B., MURAKAMI, P., ARYEE, M.J., IRIZARRY, R., HERB, B., LADD-ACOSTA, C., RHO, J., LOEWER, S. et al. (2009). Differential methylation of tissue- and cancer-specific $\mathrm{CpG}$ island shores distinguishes human induced pluripotent stem cells, embryonic stem cells and fibroblasts. Nat Genet 41: 1350-1353.

EBERHARTER, A. and BECKER, P.B. (2002). Histone acetylation: a switch between repressive and permissive chromatin. Second in review series on chromatin dynamics. EMBO Rep 3: 224-229.

ECKHARDT, F., LEWIN, J., CORTESE, R., RAKYAN, V.K., ATTWOOD, J., BURGER, M., BURTON, J., COX, T.V., DAVIES, R., DOWN, T.A. et al. (2006). DNA methylation profiling of human chromosomes 6, 20 and 22. Nat Genet 38: 1378-1385.

EGGAN, K., AKUTSU, H., HOCHEDlingER, K., RIDEOUT, W., $3^{\text {RD, }}$ YANAGIMACHI, R. and JAENISCH, R. (2000). X-Chromosome inactivation in cloned mouse embryos. Science 290: 1578-1581.

EGLI, D., BIRKHOFF, G. and EGGAN, K. (2008). Mediators of reprogramming: transcription factors and transitions through mitosis. Nat Rev Mol Cell Biol 9: 505-516.

ERHARDT, S., LYKO, F., AINSCOUGH, J.F., SURANI, M.A. and PARO, R (2003a). Polycomb-group proteins are involved in silencing processes caused by a transgenic element from the murine imprinted H19/lgf2 region in Drosophila. Dev Genes Evol 213: 336-344.

ERHARDT, S., SU, I.H., SCHNEIDER, R., BARTON, S., BANNISTER, A.J., PEREZ-BURGOS, L., JENUWEIN, T., KOUZARIDES, T., TARAKHOVSKY, A. and SURANI, M.A. (2003b). Consequences of the depletion of zygotic and embryonic enhancer of zeste 2 during preimplantation mouse development. Development 130: 4235-4248.

ESTEBAN, M.A., WANG, T., QIN, B., YANG, J., QIN, D., CAI, J., LI, W., WENG, Z., CHEN, J., NI, S. et al. Vitamin C enhances the generation of mouse and human induced pluripotent stem cells. Cell Stem Cell 6: 71-79.

ESTEVE, P.O., CHIN, H.G., SMALLWOOD, A., FEEHERY, G.R., GANGISETTY, O., KARPF, A.R., CAREY, M.F. and PRADHAN, S. (2006). Direct interaction between DNMT1 and G9a coordinates DNA and histone methylation during replication. Genes Dev 20: 3089-3103.

FAIOLA, F., LIU, X., LO, S., PAN, S., ZHANG, K., LYMAR, E., FARINA, A. and MARTINEZ, E. (2005). Dual regulation of c-Myc by p300 via acetylationdependent control of Myc protein turnover and coactivation of Myc-induced transcription. Mol Cell Biol 25: 10220-10234.

FARTHING, C.R., FICZ, G., NG, R.K., CHAN, C.F., ANDREWS, S., DEAN, W., HEMBERGER, M. and REIK, W. (2008). Global mapping of DNA methylation in mouse promoters reveals epigenetic reprogramming of pluripotency genes. PLoS Genet 4: e1000116.
FELDMAN, N., GERSON, A., FANG, J., LI, E., ZHANG, Y., SHINKAI, Y., CEDAR $\mathrm{H}$. and BERGMAN, Y. (2006). G9a-mediated irreversible epigenetic inactivation of Oct-3/4 during early embryogenesis. Nat Cell Biol 8: 188-194.

FENG, B., JIANG, J., KRAUS, P., NG, J.H., HENG, J.C., CHAN, Y.S., YAW, L.P., ZHANG, W., LOH, Y.H., HAN, J. et al. (2009). Reprogramming of fibroblasts into induced pluripotent stem cells with orphan nuclear receptor Esrrb. Nat Cell Biol 11: $197-203$

FERGUSON-SMITH, A.C. and SURANI, M.A. (2001). Imprinting and the epigenetic asymmetry between parental genomes. Science 293: 1086-1089.

FOSTER, H.A., STOKES, P., FORSEY, K., LEESE, H.J. and BRIDGER, J.M. (2007). Lamins $A$ and $C$ are present in the nuclei of early porcine embryos, with lamin A being distributed in large intranuclear foci. Chromosome Res 15: 163 174.

FULKA, H., MRAZEK, M., TEPLA, O. and FULKA, J., JR. (2004). DNA methylation pattern in human zygotes and developing embryos. Reproduction 128: 703708.

FURUYA, M., TANAKA, M., TERANISHI, T., MATSUMOTO, K., HOSOI, Y., SAEKI, K., ISHIMOTO, H., MINEGISHI, K., IRITANI, A. and YOSHIMURA, Y. (2007) $\mathrm{H} 1$ foo is indispensable for meiotic maturation of the mouse oocyte. J Reprod Dev 53: 895-902.

GATEWOOD, J.M., COOK, G.R., BALHORN, R., SCHMID, C.W. and BRADBURY, E.M. (1990). Isolation of four core histones from human sperm chromatin representing a minor subset of somatic histones. J Biol Chem 265: 20662 20666.

GIDEKEL, S., PIZOV, G., BERGMAN, Y. and PIKARSKY, E. (2003). Oct-3/4 is a dose-dependent oncogenic fate determinant. Cancer Cell 4: 361-370.

GODMANN, M., LAMBROT, R. and KIMMINS, S. (2009). The dynamic epigenetic program in male germ cells: Its role in spermatogenesis, testis cancer, and its response to the environment. Microsc Res Tech 72: 603-619.

GOEL, S., FUJIHARA, M., MINAMI, N., YAMADA, M. and IMAI, H. (2008) Expression of NANOG, but not POU5F1, points to the stem cell potential of primitive germ cells in neonatal pig testis. Reproduction 135: 785-795.

GOLDBERG, M., HAREL, A., BRANDEIS, M., RECHSTEINER, T., RICHMOND, T.J., WEISS, A.M. and GRUENBAUM, Y. (1999). The tail domain of lamin Dm0 binds histones H2A and H2B. Proc Natl Acad Sci USA 96: 2852-2857.

GOTZMANN, J. and FOISNER, R. (1999). Lamins and lamin-binding proteins in functional chromatin organization. Crit Rev Eukaryot Gene Expr 9: 257-265.

GRAVES, J.A. and YOUNG, G.J. (1982). X-chromosome activity in heterokaryons and hybrids between mouse fibroblasts and teratocarcinoma stem cells. Exp Cell Res 141: 87-97.

GRINNELL, K.L. and BICKENBACH, J.R. (2007). Skin keratinocytes pre-treated with embryonic stem cell-conditioned medium or BMP4 can be directed to an alternative cell lineage. Cell Prolif 40: 685-705.

GRINNELL, K.L., YANG, B., ECKERT, R.L. and BICKENBACH, J.R. (2007). Dedifferentiation of mouse interfollicular keratinocytes by the embryonic transcription factor Oct-4. J Invest Dermatol 127: 372-380.

GRUENBAUM, Y., MARGALIT, A., GOLDMAN, R.D., SHUMAKER, D.K. and WILSON, K.L. (2005). The nuclear lamina comes of age. Nat Rev Mol Cell Biol 6: 21-31.

GUNARATNE, P.H. (2009). Embryonic stem cell microRNAs: defining factors in induced pluripotent (iPS) and cancer (CSC) stem cells? Curr Stem Cell Res Ther 4: 168-177.

GURDON, J.B. (1962). Adult frogs derived from the nuclei of single somatic cells. Dev Biol 4: 256-273.

HAJKOVA, P., ERHARDT, S., LANE, N., HAAF, T., EL-MAARRI, O., REIK, W., WALTER, J. and SURANI, M.A. (2002). Epigenetic reprogramming in mouse primordial germ cells. Mech Dev 117: 15-23.

HALL, V.J., COONEY, M.A., SHANAHAN, P., TECIRLIOGLU, R.T., RUDDOCK, N.T. and FRENCH, A.J. (2005). Nuclear lamin antigen and messenger RNA expression in bovine in vitro produced and nuclear transfer embryos. $\mathrm{Mol}$ Reprod Dev 72: 471-482.

HAMMOUD, S., EMERY, B.R., DUNN, D., WEISS, R.B. and CARRELL, D.T. (2009a). Sequence alterations in the YBX2 gene are associated with male factor infertility. Fertil Steril 91: 1090-1095.

HAMMOUD, S.S., NIX, D.A., ZHANG, H., PURWAR, J., CARRELL, D.T. and CAIRNS, B.R. (2009b). Distinctive chromatin in human sperm packages genes 
for embryo development. Nature 460: 473-478.

HAN, D.W., DO, J.T., GENTILE, L., STEHLING, M., LEE, H.T. and SCHOLER, H.R. (2008a). Pluripotential reprogramming of the somatic genome in hybrid cells occurs with the first cell cycle. Stem Cells 26: 445-454.

HAN, X., FENG, X., RATTNER, J.B., SMITH, H., BOSE, P., SUZUKI, K., SOLIMAN, M.A., SCOTT, M.S., BURKE, B.E. and RIABOWOL, K. (2008b). Tethering by lamin A stabilizes and targets the ING1 tumour suppressor. Nat Cell Biol 10: 1333-1340.

HANNA, J., MARKOULAKI, S., SCHORDERET, P., CAREY, B.W., BEARD, C., WERNIG, M., CREYGHTON, M.P., STEINE, E.J., CASSADY, J.P., FOREMAN, R. et al. (2008). Direct reprogramming of terminally differentiated mature $B$ lymphocytes to pluripotency. Cell 133: 250-264.

HANNA, J., SAHA, K., PANDO, B., VAN ZON, J., LENGNER, C.J., CREYGHTON, M.P., VAN OUDENAARDEN, A. and JAENISCH, R. (2009). Direct cell reprogramming is a stochastic process amenable to acceleration. Nature 462: 595601.

HATA, K., OKANO, M., LEI, H. and LI, E. (2002). Dnmt3L cooperates with the Dnmt3 family of de novo DNA methyltransferases to establish maternal imprints in mice. Development 129: 1983-1993.

HONG, H., TAKAHASHI, K., ICHISAKA, T., AOI, T., KANAGAWA, O., NAKAGAWA M., OKITA, K. and YAMANAKA, S. (2009). Suppression of induced pluripotent stem cell generation by the p53-p21 pathway. Nature 460: 1132-1135.

HOULISTON, E., GUILLY, M.N., COURVALIN, J.C. and MARO, B. (1988). Expression of nuclear lamins during mouse preimplantation development. Development 102: 271-278.

HUANG, J., CHEN, T., LIU, X., JIANG, J., LI, J., LI, D., LIU, X.S., LI, W., KANG, J. and PEI, G. (2009). More synergetic cooperation of Yamanaka factors in induced pluripotent stem cells than in embryonic stem cells. Cell Res 19: 11271138.

HUANGFU, D., MAEHR, R., GUO, W., EIJKELENBOOM, A., SNITOW, M., CHEN, A.E. and MELTON, D.A. (2008a). Induction of pluripotent stem cells by defined factors is greatly improved by small-molecule compounds. Nat Biotechnol 26: 795-797.

HUANGFU, D., OSAFUNE, K., MAEHR, R., GUO, W., EIJKELENBOOM, A., CHEN, S., MUHLESTEIN, W. and MELTON, D.A. (2008b). Induction of pluripotent stem cells from primary human fibroblasts with only Oct4 and Sox2. Nat Biotechnol 26: 1269-1275.

HYSLOP, L., STOJKOVIC, M., ARMSTRONG, L., WALTER, T., STOJKOVIC, P., PRZYBORSKI, S., HERBERT, M., MURDOCH, A., STRACHAN, T. and LAKO, M. (2005). Downregulation of NANOG induces differentiation of human embryonic stem cells to extraembryonic lineages. Stem Cells 23: 1035-1043.

ILLINGWORTH, R., KERR, A., DESOUSA, D., JORGENSEN, H., ELLIS, P., STALKER, J., JACKSON, D., CLEE, C., PLUMB, R., ROGERS, J. et al. (2008). A novel $\mathrm{CpG}$ island set identifies tissue-specific methylation at developmental gene loci. PLoS Biol 6: e22.

IVANOVA, N., DOBRIN, R., LU, R., KOTENKO, I., LEVORSE, J., DECOSTE, C., SCHAFER, X., LUN, Y. and LEMISCHKA, I.R. (2006). Dissecting self-renewal in stem cells with RNA interference. Nature 442: 533-538.

JAENISCH, R. and YOUNG, R. (2008). Stem cells, the molecular circuitry of pluripotency and nuclear reprogramming. Cell 132: 567-582.

JEDRUSIK, A., PARFITT, D.E., GUO, G., SKAMAGKI, M., GRABAREK, J.B. JOHNSON, M.H., ROBSON, P. and ZERNICKA-GOETZ, M. (2008). Role of $\mathrm{Cdx} 2$ and cell polarity in cell allocation and specification of trophectoderm and inner cell mass in the mouse embryo. Genes Dev 22: 2692-2706.

$\mathrm{JI}, \mathrm{Z}$. and TIAN, B. (2009). Reprogramming of 3 ' untranslated regions of mRNAs by alternative polyadenylation in generation of pluripotent stem cells from different cell types. PLoS One 4: e8419.

JOHN, S.A. and GARRETT-SINHA, L.A. (2009). Blimp1: a conserved transcriptional repressor critical for differentiation of many tissues. Exp Cell Res 315: 1077-1084.

KAGEYAMA, S., LIU, H., KANEKO, N., OOGA, M., NAGATA, M. and AOKI, F. (2007). Alterations in epigenetic modifications during oocyte growth in mice. Reproduction 133: 85-94.

KAJI, K., NORRBY, K., PACA, A., MILEIKOVSKY, M., MOHSENI, P. and WOLTJEN, K. (2009). Virus-free induction of pluripotency and subsequent excision of reprogramming factors. Nature 458: 771-775.
KANEDA, M., OKANO, M., HATA, K., SADO, T., TSUJIMOTO, N., LI, E. and SASAKI, H. (2004). Essential role for de novo DNA methyltransferase Dnmt3a in paternal and maternal imprinting. Nature 429: 900-903.

$\mathrm{KATOH}, \mathrm{Y}$. and KATOH, M. (2007). Comparative integromics on JMJD2A, JMJD2B and JMJD2C: preferential expression of JMJD2C in undifferentiated ES cells. Int $\mathrm{J}$ Mol Med 20: 269-273.

KATZ, D.J., EDWARDS, T.M., REINKE, V. and KELLY, W.G. (2009). A C. elegans LSD1 demethylase contributes to germline immortality by reprogramming epigenetic memory. Cell 137: 308-320.

KAWAMURA, T., SUZUKI, J., WANG, Y.V., MENENDEZ, S., MORERA, L.B., RAYA, A., WAHL, G.M. and BELMONTE, J.C. (2009). Linking the p53 tumour suppressor pathway to somatic cell reprogramming. Nature 460: 1140-1144.

KIMMINS, S. and SASSONE-CORSI, P. (2005). Chromatin remodelling and epigenetic features of germ cells. Nature 434: 583-589.

KNOEPFLER, P.S., ZHANG, X.Y., CHENG, P.F., GAFKEN, P.R., MCMAHON, S.B. and EISENMAN, R.N. (2006). Myc influences global chromatin structure. EMBO J 25: 2723-2734.

KOURMOULI, N., JEPPESEN, P., MAHADEVHAIAH, S., BURGOYNE, P., WU, R., GILBERT, D.M., BONGIORNI, S., PRANTERA, G., FANTI, L., PIMPINELLI, S. et al. (2004). Heterochromatin and tri-methylated lysine 20 of histone $\mathrm{H} 4$ in animals. J Cell Sci 117: 2491-2501.

KRENTZ, A.D., MURPHY, M.W., KIM, S., COOK, M.S., CAPEL, B., ZHU, R., MATIN, A., SARVER, A.L., PARKER, K.L., GRISWOLD, M.D. et al. (2009). The DM domain protein DMRT1 is a dose-sensitive regulator of fetal germ cel proliferation and pluripotency. Proc Natl Acad Sci USA 106: 22323-22328.

$\mathrm{KU}$, M., KOCHE, R.P., RHEINBAY, E., MENDENHALL, E.M., ENDOH, M., MIKKELSEN, T.S., PRESSER, A., NUSBAUM, C., XIE, X., CHI, A.S. et al (2008). Genomewide analysis of PRC1 and PRC2 occupancy identifies two classes of bivalent domains. PLoS Genet 4: e1000242.

KUBICEK, S., SCHOTTA, G., LACHNER, M., SENGUPTA, R., KOHLMAIER, A. PEREZ-BURGOS, L., LINDERSON, Y., MARTENS, J.H., O'SULLIVAN, R.J. FODOR, B.D. et al. (2006). The role of histone modifications in epigenetic transitions during normal and perturbed development. Ernst Schering Res Found Workshop1-27.

KURAMOCHI-MIYAGAWA, S., WATANABE, T., GOTOH, K., TOTOKI, Y., TOYODA A., IKAWA, M., ASADA, N., KOJIMA, K., YAMAGUCHI, Y., IJIRI, T.W. et al. (2008). DNA methylation of retrotransposon genes is regulated by Piwi family members MILI and MIWI2 in murine fetal testes. Genes Dev 22: 908-917.

KURIHARA, Y., KAWAMURA, Y., UCHIJIMA, Y., AMAMO, T., KOBAYASHI, H., ASANO, T. and KURIHARA, H. (2008). Maintenance of genomic methylation patterns during preimplantation development requires the somatic form of DNA methyltransferase 1. Dev Biol 313: 335-346.

KWON, S.Y., XIAO, H., WU, C. and BADENHORST, P. (2009). Alternative splicing of NURF301 generates distinct NURF chromatin remodeling complexes with altered modified histone binding specificities. PLoS Genet 5: e1000574.

LEE, J., INOUE, K., ONO, R., OGONUKI, N., KOHDA, T., KANEKO-ISHINO, T., OGURA, A. and ISHINO, F. (2002). Erasing genomic imprinting memory in mouse clone embryos produced from day 11.5 primordial germ cells. Develop ment 129: 1807-1817.

LEES-MURDOCK, D.J. and WALSH, C.P. (2008). DNA methylation reprogramming in the germ line. Adv Exp Med Biol 626: 1-15

LEFEVRE, C. and MANN, J.R. (2008). RNA expression microarray analysis in mouse prospermatogonia: identification of candidate epigenetic modifiers. Dev Dyn 237: 1082-1089.

LEHNERTZ, B., UEDA, Y., DERIJCK, A.A., BRAUNSCHWEIG, U., PEREZBURGOS, L., KUBICEK, S., CHEN, T., LI, E., JENUWEIN, T. and PETERS, A.H. (2003). Suv39h-mediated histone H3 lysine 9 methylation directs DNA methylation to major satellite repeats at pericentric heterochromatin. Curr Biol 13: $1192-1200$.

LEPIKHOV, K. and WALTER, J. (2004). Differential dynamics of histone H3 methylation at positions K4 and K9 in the mouse zygote. BMC Dev Biol 4: 12.

LI, G., MARGUERON, R., KU, M., CHAMBON, P., BERNSTEIN, B.E. and REINBERG, D. Jarid2 and PRC2, partners in regulating gene expression (2010). Genes Dev 24: 368-380.

LI, H., COLLADO, M., VILLASANTE, A., STRATI, K., ORTEGA, S., CANAMERO, M., BLASCO, M.A. and SERRANO, M. (2009). The Ink4/Arf locus is a barrier for 
iPS cell reprogramming. Nature 460: 1136-1139.

LI, Y.Q. Master stem cell transcription factors and signaling regulation (2010). Cloning Stem Cells 12: 3-13.

LIN, S.P., YOUNGSON, N., TAKADA, S., SEITZ, H., REIK, W., PAULSEN, M., CAVAILLE, J. and FERGUSON-SMITH, A.C. (2003). Asymmetric regulation of imprinting on the maternal and paternal chromosomes at the Dlk1-Gtl2 imprinted cluster on mouse chromosome 12. Nat Genet 35: 97-102.

LIN, T., CHAO, C., SAITO, S., MAZUR, S.J., MURPHY, M.E., APPELLA, E. and XU, Y. (2005). p53 induces differentiation of mouse embryonic stem cells by suppressing Nanog expression. Nat Cell Biol 7: 165-171.

LIU, H., KIM, J.M. and AOKI, F. (2004). Regulation of histone H3 lysine 9 methylation in oocytes and early pre-implantation embryos. Development 131 : 2269-2280.

LIU, X., VORONTCHIKHINA, M., WANG, Y.L., FAIOLA, F. and MARTINEZ, E. (2008). STAGA recruits Mediator to the MYC oncoprotein to stimulate transcription and cell proliferation. Mol Cell Biol 28: 108-121.

LLOYD, D.J., TREMBATH, R.C. and SHACKLETON, S. (2002). A novel interaction between lamin A and SREBP1: implications for partial lipodystrophy and other laminopathies. Hum Mol Genet 11: 769-777.

LOH, Y.H., WU, Q., CHEW, J.L., VEGA, V.B., ZHANG, W., CHEN, X., BOURQUE, G., GEORGE, J., LEONG, B., LIU, J. et al. (2006). The Oct4 and Nanog transcription network regulates pluripotency in mouse embryonic stem cells. Nat Genet 38: 431-440.

LOHMANN, F., LOUREIRO, J., SU, H., FANG, Q., LEI, H., LEWIS, T., YANG, Y., LABOW, M., LI, E., CHEN, T. et al. KMT1E mediated H3K9 methylation is required for the maintenance of embryonic stem cells by repressing trophectoderm differentiation. Stem Cells 28: 201-212.

LUCCHESI, J.C., KELLY, W.G. and PANNING, B. (2005). Chromatin remodeling in dosage compensation. Annu Rev Genet 39: 615-651.

LUCIFERO, D., LA SALLE, S., BOURC'HIS, D., MARTEL, J., BESTOR, T.H. and TRASLER, J.M. (2007). Coordinate regulation of DNA methyltransferase expression during oogenesis. BMC Dev Biol 7: 36.

LUCIFERO, D., MANN, M.R., BARTOLOMEI, M.S. and TRASLER, J.M. (2004). Gene-specific timing and epigenetic memory in oocyte imprinting. Hum Mol Genet 13: 839-849.

LYON, M.F. (1961). Gene action in the X-chromosome of the mouse (Mus musculus L.). Nature 190: 372-373.

MA, D.K., CHIANG, C.H., PONNUSAMY, K., MING, G.L. and SONG, H. (2008). G9a and Jhdm2a regulate embryonic stem cell fusion-induced reprogramming of adult neural stem cells. Stem Cells 26: 2131-2141.

MA, Y., RAMEZANI, A., LEWIS, R., HAWLEY, R.G. and THOMSON, J.A. (2003). High-level sustained transgene expression in human embryonic stem cells using lentiviral vectors. Stem Cells 21: 111-117.

MAHERALI, N., AHFELDT, T., RIGAMONTI, A., UTIKAL, J., COWAN, C. and HOCHEDLINGER, K. (2008). A high-efficiency system for the generation and study of human induced pluripotent stem cells. Cell Stem Cell 3: 340-345.

MAHERALI, N. and HOCHEDLINGER, K. (2008). Guidelines and techniques for the generation of induced pluripotent stem cells. Cell Stem Cell 3: 595-605.

MAHERALI, N., SRIDHARAN, R., XIE, W., UTIKAL, J., EMINLI, S., ARNOLD, K., STADTFELD, M., YACHECHKO, R., TCHIEU, J., JAENISCH, R. et al. (2007). Directly reprogrammed fibroblasts show global epigenetic remodeling and widespread tissue contribution. Cell Stem Cell 1: 55-70.

MANN, J.R., SZABO, P.E., REED, M.R. and SINGER-SAM, J. (2000). Methylated DNA sequences in genomic imprinting. Crit Rev Eukaryot Gene Expr 10: 241 257.

MANN, M.R., CHUNG, Y.G., NOLEN, L.D., VERONA, R.I., LATHAM, K.E. and BARTOLOMEI, M.S. (2003). Disruption of imprinted gene methylation and expression in cloned preimplantation stage mouse embryos. Biol Reprod 69: 902-914.

MARALDI, N.M., CAPANNI, C., LATTANZI, G., CAMOZZI, D., FACCHINI, A. and MANZOLI, F.A. (2008). SREBP1 interaction with prelamin A forms: a pathogenic mechanism for lipodystrophic laminopathies. Adv Enzyme Regul 48: 209223.

MARION, R.M., STRATI, K., LI, H., MURGA, M., BLANCO, R., ORTEGA, S., FERNANDEZ-CAPETILLO, O., SERRANO, M. and BLASCO, M.A. (2009). A p53-mediated DNA damage response limits reprogramming to ensure iPS cell genomic integrity. Nature 460: 1149-1153.

MARTIN, C. and ZHANG, Y. (2005). The diverse functions of histone lysine methylation. Nat Rev Mol Cell Biol 6: 838-849.

MATOBA, R., NIWA, H., MASUI, S., OHTSUKA, S., CARTER, M.G., SHAROV, A.A. and KO, M.S. (2006). Dissecting Oct3/4-regulated gene networks in embryonic stem cells by expression profiling. PLoS One 1: e26.

MATTOUT, A., GOLDBERG, M., TZUR, Y., MARGALIT, A. and GRUENBAUM, Y. (2007). Specific and conserved sequences in D. melanogaster and C. elegans lamins and histone H2A mediate the attachment of lamins to chromosomes. $J$ Cell Sci 120: 77-85.

MATVEEVA, N.M., SHILOV, A.G., KAFTANOVSKAYA, E.M., MAXIMOVSKY, L.P. ZHELEZOVA, A.I., GOLUBITSA, A.N., BAYBORODIN, S.I., FOKINA, M.M. and SEROV, O.L. (1998). In vitro and in vivo study of pluripotency in intraspecific hybrid cells obtained by fusion of murine embryonic stem cells with splenocytes. Mol Reprod Dev 50: 128-138.

MAYER, W., SMITH, A., FUNDELE, R. and HAAF, T. (2000). Spatial separation of parental genomes in preimplantation mouse embryos. J Cell Biol 148: 629-634.

MCLAREN, A. (2003). Primordial germ cells in the mouse. Dev Biol 262: 1-15.

MCLAY, D.W. and CLARKE, H.J. (2003). Remodelling the paternal chromatin at fertilization in mammals. Reproduction 125: 625-633.

MELCON, G., KOZLOV, S., CUTLER, D.A., SULLIVAN, T., HERNANDEZ, L., ZHAO, P., MITCHELL, S., NADER, G., BAKAY, M., ROTTMAN, J.N. et al. (2006). Loss of emerin at the nuclear envelope disrupts the Rb1/E2F and MyoD pathways during muscle regeneration. Hum Mol Genet 15: 637-651.

MENDEZ-ACUNA, L., DI TOMASO, M.V., PALITTI, F. and MARTINEZ-LOPEZ, W. (2010). Histone Post-Translational Modifications in DNA Damage Response. Cytogenet Genome Res 128: 28-36

MESHORER, E., YELLAJOSHULA, D., GEORGE, E., SCAMBLER, P.J., BROWN D.T. and MISTELI, T. (2006). Hyperdynamic plasticity of chromatin proteins in pluripotent embryonic stem cells. Dev Cell 10: 105-116.

MIKKELSEN, T.S., HANNA, J., ZHANG, X., KU, M., WERNIG, M., SCHORDERET, P., BERNSTEIN, B.E., JAENISCH, R., LANDER, E.S. and MEISSNER, A. (2008). Dissecting direct reprogramming through integrative genomic analysis. Nature 454: 49-55.

MINAMI, N., SUZUKI, T. and TSUKAMOTO, S. (2007). Zygotic gene activation and maternal factors in mammals. J Reprod Dev 53: 707-715.

MISE, N., SADO, T., TADA, M., TAKADA, S. and TAKAGI, N. (1996). Activation of the inactive $X$ chromosome induced by cell fusion between a murine $E C$ and female somatic cell accompanies reproducible changes in the methylation pattern of the Xist gene. Exp Cell Res 223: 193-202.

MITSUI, K., TOKUZAWA, Y., ITOH, H., SEGAWA, K., MURAKAMI, M., TAKAHASHI, K., MARUYAMA, M., MAEDA, M. and YAMANAKA, S. (2003). The homeoprotein Nanog is required for maintenance of pluripotency in mouse epiblast and ES cells. Cell 113: 631-642.

MONK, M. (1987). Genomic imprinting. Memories of mother and father. Nature 328 : 203-204.

MONTES DE OCA, R., LEE, K.K. and WILSON, K.L. (2005). Binding of barrier to autointegration factor (BAF) to histone $\mathrm{H} 3$ and selected linker histones including H1.1. J Biol Chem 280: 42252-42262.

MULLIN, N.P., YATES, A., ROWE, A.J., NIJMEIJER, B., COLBY, D., BARLOW, P.N., WALKINSHAW, M.D. and CHAMBERS, I. (2008). The pluripotency rheostat Nanog functions as a dimer. Biochem J 411: 227-231.

NAKATAKE, Y., FUKUI, N., IWAMATSU, Y., MASUI, S., TAKAHASHI, K., YAGI, R., YAGI, K., MIYAZAKI, J., MATOBA, R., KO, M.S. et al. (2006). Klf4 cooperates with Oct3/4 and Sox2 to activate the Lefty1 core promoter in embryonic stem cells. Mol Cell Biol 26: 7772-7782.

NG, R.K. and GURDON, J.B. (2008a). Epigenetic inheritance of cell differentiation status. Cell Cycle 7: 1173-1177.

NG, R.K. and GURDON, J.B. (2008b). Epigenetic memory of an active gene state depends on histone H3.3 incorporation into chromatin in the absence of transcription. Nat Cell Biol 1: 102-109.

NICHOLS, J., ZEVNIK, B., ANASTASSIADIS, K., NIWA, H., KLEWE-NEBENIUS, D., CHAMBERS, I., SCHOLER, H. and SMITH, A. (1998). Formation of pluripotent stem cells in the mammalian embryo depends on the POU transcrip- 
tion factor Oct4. Cell 95: 379-391.

NISHIOKA, N., YAMAMOTO, S., KIYONARI, H., SATO, H., SAWADA, A., OTA, M., NAKAO, K. and SASAKI, H. (2008). Tead4 is required for specification of trophectoderm in pre-implantation mouse embryos. Mech Dev 125: 270-283.

NIWA, H., MIYAZAKI, J. and SMITH, A.G. (2000). Quantitative expression of Oct$3 / 4$ defines differentiation, dedifferentiation or self-renewal of ES cells. Nat Genet 24: 372-6.

NIWA, H., TOYOOKA, Y., SHIMOSATO, D., STRUMPF, D., TAKAHASHI, K., YAGI, R. and ROSSANT, J. (2005). Interaction between Oct3/4 and Cdx2 determines trophectoderm differentiation. Cell 123: 917-929.

NOLEN, L.D., GAO, S., HAN, Z., MANN, M.R., GIE CHUNG, Y., OTTE, A.P., BARTOLOMEI, M.S. and LATHAM, K.E. (2005). X chromosome reactivation and regulation in cloned embryos. Dev Biol 279: 525-540.

O'CARROLL, D., ERHARDT, S., PAGANI, M., BARTON, S.C., SURANI, M.A. and JENUWEIN, T. (2001). The polycomb-group gene Ezh2 is required for early mouse development. Mol Cell Biol 21: 4330-4336.

OAKES, C.C., LA SALLE, S., SMIRAGLIA, D.J., ROBAIRE, B. and TRASLER, J.M. (2007). Developmental acquisition of genome-wide DNA methylation occurs prior to meiosis in male germ cells. Dev Biol 307: 368-379.

OBATA, Y., KONO, T. and HATADA, I. (2002). Gene silencing: maturation of mouse fetal germ cells in vitro. Nature 418: 497.

OGAWA, Y. and LEE, J.T. (2003). Xite, X-inactivation intergenic transcription elements that regulate the probability of choice. Mol Cell 11: 731-743.

OHINATA, Y., PAYER, B., O'CARROLL, D., ANCELIN, K., ONO, Y., SANO, M., BARTON, S.C., OBUKHANYCH, T., NUSSENZWEIG, M., TARAKHOVSKY, A. et al. (2005). Blimp1 is a critical determinant of the germ cell lineage in mice. Nature 436: 207-213

OKITA, K., ICHISAKA, T. and YAMANAKA, S. (2007). Generation of germlinecompetent induced pluripotent stem cells. Nature 448: 313-317.

OLLINGER, R., REICHMANN, J. and ADAMS, I.R. (2010). Meiosis and retrotransposon silencing during germ cell development in mice. Differentiation 79: 147-158.

OSWALD, J., ENGEMANN, S., LANE, N., MAYER, W., OLEK, A., FUNDELE, R., DEAN, W., REIK, W. and WALTER, J. (2000). Active demethylation of the paternal genome in the mouse zygote. Curr Biol 10: 475-478.

PAN, G. and THOMSON, J.A. (2007). Nanog and transcriptional networks in embryonic stem cell pluripotency. Cell Res 17: 42-49.

PARK, I.H., ZHAO, R., WEST, J.A., YABUUCHI, A., HUO, H., INCE, T.A., LEROU, P.H., LENSCH, M.W. and DALEY, G.Q. (2008). Reprogramming of human somatic cells to pluripotency with defined factors. Nature 451: 141-146.

PARK, J., KUNJIBETTU, S., MCMAHON, S.B. and COLE, M.D. (2001). The ATMrelated domain of TRRAP is required for histone acetyltransferase recruitment and Myc-dependent oncogenesis. Genes Dev 15: 1619-1624.

PARNAIK, V.K. (2008). Role of nuclear lamins in nuclear organization, cellular signaling, and inherited diseases. Int Rev Cell Mol Biol 266: 157-206.

PASINI, D., CLOOS, P.A., WALFRIDSSON, J., OLSSON, L., BUKOWSKI, J.P., JOHANSEN, J.V., BAK, M., TOMMERUP, N., RAPPSILBER, J. and HELIN, K. JARID2 regulates binding of the Polycomb repressive complex 2 to target genes in ES cells. Nature 464: 306-310.

PAYNE, C. and BRAUN, R.E. (2006). Histone lysine trimethylation exhibits a distinct perinuclear distribution in Plzf-expressing spermatogonia. Dev Biol293: 461-472.

PEDERSEN, R.A., WU, K. and BALAKIER, H. (1986). Origin of the inner cell mass in mouse embryos: cell lineage analysis by microinjection. Dev Biol 117: 581595.

PESCE, M., WANG, X., WOLGEMUTH, D.J. and SCHOLER, H. (1998). Differential expression of the Oct-4 transcription factor during mouse germ cell differentiation. Mech Dev 71: 89-98.

PETERS, J. and ROBSON, J.E. (2008). Imprinted noncoding RNAs. Mamm Genome 19: 493-502.

PICK, M., STELZER, Y., BAR-NUR, O., MAYSHAR, Y., EDEN, A. and BENVENISTY, N. (2009). Clone- and gene-specific aberrations of parental imprinting in human induced pluripotent stem cells. Stem Cells 27: 2686-2690.

PROKOCIMER, M., DAVIDOVICH, M., NISSIM-RAFINIA, M., WIESEL-MOTIUK, N., BAR, D., BARKAN, R., MESHORER, E. and GRUENBAUM, Y. (2009).
Nuclear lamins: key regulators of nuclear structure and activities. J Cell Mol Med 13: 1059-1085.

PUSCHENDORF, M., TERRANOVA, R., BOUTSMA, E., MAO, X., ISONO, K., BRYKCZYNSKA, U., KOLB, C., OTTE, A.P., KOSEKI, H., ORKIN, S.H. et al. (2008). PRC1 and Suv39h specify parental asymmetry at constitutive heterochromatin in early mouse embryos. Nat Genet 40: 411-420.

RACEDO, S.E., WRENZYCKI, C., LEPIKHOV, K., SALAMONE, D., WALTER, J. and NIEMANN, H. (2009). Epigenetic modifications and related mRNA expression during bovine oocyte in vitro maturation. Reprod Fertil Dev 21: 738-748.

RASMUSSEN, T.P. (2008). Developmentally-poised chromatin of embryonic stem cells. Front Biosci 13: 1568-1577.

RAVEROT, G., WEISS, J., PARK, S.Y., HURLEY, L. and JAMESON, J.L. (2005). Sox3 expression in undifferentiated spermatogonia is required for the progression of spermatogenesis. Dev Biol 283: 215-225.

REIK, W. (2007). Stability and flexibility of epigenetic gene regulation in mammalian development. Nature 447: 425-432.

REIK, W. and WALTER, J. (2001). Genomic imprinting: parental influence on the genome. Nat Rev Genet 2: 21-32.

REN, B., CHEE, K.J., KIM, T.H. and MANIATIS, T. (1999). PRDI-BF1/Blimp-1 repression is mediated by corepressors of the Groucho family of proteins. Genes Dev 13: 125-137.

ROUGIER, N., BOURC'HIS, D., GOMES, D.M., NIVELEAU, A., PLACHOT, M., PALDI, A. and VIEGAS-PEQUIGNOT, E. (1998). Chromosome methylation patterns during mammalian preimplantation development. Genes Dev 12 2108-2113.

ROWLAND, B.D., BERNARDS, R. and PEEPER, D.S. (2005). The KLF4 tumour suppressor is a transcriptional repressor of p53 that acts as a context-dependent oncogene. Nat Cell Biol 7: 1074-1082.

ROWLAND, B.D. and PEEPER, D.S. (2006). KLF4, p21 and context-dependent opposing forces in cancer. Nat Rev Cancer 6: 11-23.

RUSS, A.P., WATTLER, S., COLLEDGE, W.H., APARICIO, S.A., CARLTON, M.B., PEARCE, J.J., BARTON, S.C., SURANI, M.A., RYAN, K., NEHLS, M.C. et al (2000). Eomesodermin is required for mouse trophoblast development and mesoderm formation. Nature 404: 95-99.

SANTOS, F., HENDRICH, B., REIK, W. and DEAN, W. (2002). Dynamic reprogramming of DNA methylation in the early mouse embryo. Dev Biol 241: 172-182.

SANTOS, F., PETERS, A.H., OTTE, A.P., REIK, W. and DEAN, W. (2005). Dynamic chromatin modifications characterise the first cell cycle in mouse embryos. Dev Biol 280: 225-236.

SANTOS, F., ZAKHARTCHENKO, V., STOJKOVIC, M., PETERS, A., JENUWEIN, T., WOLF, E., REIK, W. and DEAN, W. (2003). Epigenetic marking correlates with developmental potential in cloned bovine preimplantation embryos. Curr Biol 13: 1116-1121.

SARG, B., CHWATAL, S., TALASZ, H. and LINDNER, H.H. (2009). Testis-specific linker histone $\mathrm{H} 1 \mathrm{t}$ is multiply phosphorylated during spermatogenesis. Identification of phosphorylation sites. J Biol Chem 284: 3610-3618.

SCHATTEN, G., MAUL, G.G., SCHATTEN, H., CHALY, N., SIMERLY, C., BALCZON, R. and BROWN, D.L. (1985). Nuclear lamins and peripheral nuclear antigens during fertilization and embryogenesis in mice and sea urchins. Proc Natl Acad SCi USA 82: 4727-4731.

SCHEPER, W. and COPRAY, S. (2009). The molecular mechanism of induced pluripotency: a two-stage switch. Stem Cell Rev 5: 204-223.

SCHIER, A.F. (2007). The maternal-zygotic transition: death and birth of RNAs. Science 316: 406-407.

SCHNETZ, M.P., BARTELS, C.F., SHASTRI, K., BALASUBRAMANIAN, D. ZENTNER, G.E., BALAJI, R., ZHANG, X., SONG, L., WANG, Z., LAFRAMBOISE, T. et al. (2009). Genomic distribution of CHD7 on chromatin tracks H3K4 methylation patterns. Genome Res 19: 590-601.

SCHOLER, H.R., BALLING, R., HATZOPOULOS, A.K., SUZUKI, N. and GRUSS, P. (1989a). Octamer binding proteins confer transcriptional activity in early mouse embryogenesis. EMBO J 8: 2551-2557.

SCHOLER, H.R., HATZOPOULOS, A.K., BALLING, R., SUZUKI, N. and GRUSS, P. (1989b). A family of octamer-specific proteins present during mouse embryogenesis: evidence for germline-specific expression of an Oct factor. EMBO J 8 : 2543-2550. 
SCHULTZ, R.M. (2002). The molecular foundations of the maternal to zygotic transition in the preimplantation embryo. Hum Reprod Update 8: 323-331.

SHAO, L., FENG, W., SUN, Y., BAI, H., LIU, J., CURRIE, C., KIM, J., GAMA, R., WANG, Z., QIAN, Z. et al. (2009). Generation of iPS cells using defined factors linked via the self-cleaving $2 \mathrm{~A}$ sequences in a single open reading frame.nCell Res 19: 296-306.

SHAROV, A.A., MASUI, S., SHAROVA, L.V., PIAO, Y., AIBA, K., MATOBA, R., XIN, L., NIWA, H. and KO, M.S. (2008). Identification of Pou5f1, Sox2, and Nanog downstream target genes with statistical confidence by applying a novel algorithm to time course microarray and genome-wide chromatin immunoprecipitation data. BMC Genomics 9: 269.

SHI, L.H., MIAO, Y.L., OUYANG, Y.C., HUANG, J.C., LEI, Z.L., YANG, J.W., HAN Z.M., SONG, X.F., SUN, Q.Y. and CHEN, D.Y. (2008). Trichostatin A (TSA) improves the development of rabbit-rabbit intraspecies cloned embryos, but not rabbit-human interspecies cloned embryos. Dev Dyn 237: 640-648.

SHI, W., DIRIM, F., WOLF, E., ZAKHARTCHENKO, V. and HAAF, T. (2004a). Methylation reprogramming and chromosomal aneuploidy in vivo fertilized and cloned rabbit preimplantation embryos. Biol Reprod 71: 340-347.

SHI, Y., LAN, F., MATSON, C., MULLIGAN, P., WHETSTINE, J.R., COLE, P.A. and CASERO, R.A. (2004b). Histone demethylation mediated by the nuclear amine oxidase homolog LSD1. Cell 119: 941-953.

SILVA, J., NICHOLS, J., THEUNISSEN, T.W., GUO, G., VAN OOSTEN, A.L., BARRANDON, O., WRAY, J., YAMANAKA, S., CHAMBERS, I. and SMITH, A. (2009). Nanog is the gateway to the pluripotent ground state. Cell 138: 722-737.

SMITH, K.P., LUONG, M.X. and STEIN, G.S. (2009). Pluripotency: toward a gold standard for human ES and iPS cells. J Cell Physiol 220: 21-29.

SOLDNER, F., HOCKEMEYER, D., BEARD, C., GAO, Q., BELL, G.W., COOK, E.G., HARGUS, G., BLAK, A., COOPER, O., MITALIPOVA, M. et al. (2009). Parkinson's disease patient-derived induced pluripotent stem cells free of viral reprogramming factors. Cell 136: 964-977.

STADTFELD, M., APOSTOLOU, E., AKUTSU, H., FUKUDA, A., FOLLETT, P., NATESAN, S., KONO, T., SHIODA, T. and HOCHEDLINGER, K. Aberrant silencing of imprinted genes on chromosome 12qF1 in mouse induced pluripotent stem cells (2010). Nature 465: 175-181.

STADTFELD, M., NAGAYA, M., UTIKAL, J., WEIR, G. and HOCHEDLINGER, K. (2008). Induced pluripotent stem cells generated without viral integration. Science 322: 945-949.

STAVROPOULOS, N., ROWNTREE, R.K. and LEE, J.T. (2005). Identification of developmentally specific enhancers for Tsix in the regulation of $\mathrm{X}$ chromosome inactivation. Mol Cell Biol 25: 2757-2769.

STEWART, M.D., SOMMERVILLE, J. and WONG, J. (2006). Dynamic regulation of histone modifications in Xenopus oocytes through histone exchange. Mol Cell Biol 26: 6890-6901.

STRUMPF, D., MAO, C.A., YAMANAKA, Y., RALSTON, A., CHAWENGSAKSOPHAK, K., BECK, F. and ROSSANT, J. (2005). Cdx2 is required for correct cell fate specification and differentiation of trophectoderm in the mouse blastocyst. Development 132: 2093-2102.

SUGIMOTO, M. and ABE, K. (2007). X chromosome reactivation initiates in nascent primordial germ cells in mice. PLoS Genet 3: e116.

SUN, A., TAWFIK, O., GAYED, B., THRASHER, J.B., HOESTJE, S., LI, C. and LI, B. (2007). Aberrant expression of SWI/SNF catalytic subunits BRG1/BRM is associated with tumor development and increased invasiveness in prostate cancers. Prostate 67: 203-213.

SWANN, K., SAUNDERS, C.M., ROGERS, N.T. and LAI, F.A. (2006). PLCzeta(zeta): a sperm protein that triggers $\mathrm{Ca} 2+$ oscillations and egg activation in mammals. Semin Cell Dev Biol 17: 264-273.

SZABO, P.E. and MANN, J.R. (1995). Biallelic expression of imprinted genes in the mouse germ line: implications for erasure, establishment, and mechanisms of genomic imprinting. Genes Dev 9: 1857-1868.

TADA, M., MORIZANE, A., KIMURA, H., KAWASAKI, H., AINSCOUGH, J.F., SASAI, Y., NAKATSUJI, N. and TADA, T. (2003). Pluripotency of reprogrammed somatic genomes in embryonic stem hybrid cells. Dev Dyn 227: 504510.

TADA, M., TADA, T., LEFEBVRE, L., BARTON, S.C. and SURANI, M.A. (1997). Embryonic germ cells induce epigenetic reprogramming of somatic nucleus in hybrid cells. EMBO J 16: 6510-6520.
TADA, M., TAKAHAMA, Y., ABE, K., NAKATSUJI, N. and TADA, T. (2001). Nuclear reprogramming of somatic cells by in vitro hybridization with ES cells. Curr Biol 11: 1553-1558.

TAKAGI, N. (1993). Variable X chromosome inactivation patterns in near-tetraploid murine EC x somatic cell hybrid cells differentiated in vitro. Genetica 88: 107117.

TAKAHASHI, K., TANABE, K., OHNUKI, M., NARITA, M., ICHISAKA, T., TOMODA, K. and YAMANAKA, S. (2007). Induction of pluripotent stem cells from adult human fibroblasts by defined factors. Cell 131: 861-872.

TAKAHASHI, K. and YAMANAKA, S. (2006). Induction of pluripotent stem cells from mouse embryonic and adult fibroblast cultures by defined factors. Cell 126: 663-676.

TAKEUCHI, T., WATANABE, Y., TAKANO-SHIMIZU, T. and KONDO, S. (2006). Roles of jumonji and jumonji family genes in chromatin regulation and development. Dev Dyn 235: 2449-2459.

TANAKA, M., HENNEBOLD, J.D., MACFARLANE, J. and ADASHI, E.Y. (2001). A mammalian oocyte-specific linker histone gene $\mathrm{H} 100$ : homology with the genes for the oocyte-specific cleavage stage histone (cs-H1) of sea urchin and the B4/ H1M histone of the frog. Development 128: 655-664.

TANPHAICHITR, N., SOBHON, P., TALUPPETH, N. and CHALERMISARACHAI, P. (1978). Basic nuclear proteins in testicular cells and ejaculated spermatozoa in man. Exp Cell Res 117: 347-356.

TATE, C.M., LEE, J.H. and SKALNIK, D.G. (2010). CXXC finger protein 1 restricts the Setd1A histone H3K4 methyltransferase complex to euchromatin. FEBS $J$ 277: 210-223.

TELFORD, N.A., WATSON, A.J. and SCHULTZ, G.A. (1990). Transition from maternal to embryonic control in early mammalian development: a comparison of several species. Mol Reprod Dev 26: 90-100.

THORVALDSEN, J.L., DURAN, K.L. and BARTOLOMEI, M.S. (1998). Deletion of the $\mathrm{H} 19$ differentially methylated domain results in loss of imprinted expression of $\mathrm{H} 19$ and Igf2. Genes Dev 12: 3693-3702.

TORRES-PADILLA, M.E., BANNISTER, A.J., HURD, P.J., KOUZARIDES, T. and ZERNICKA-GOETZ, M. (2006). Dynamic distribution of the replacement histone variant $\mathrm{H} 3.3$ in the mouse oocyte and preimplantation embryos. Int J Dev Biol 50: 455-461.

TORRES-PADILLA, M.E., PARFITT, D.E., KOUZARIDES, T. and ZERNICKAGOETZ, M. (2007). Histone arginine methylation regulates pluripotency in the early mouse embryo. Nature 445: 214-218.

TUNYAPLIN, C., SHAPIRO, M.A. and CALAME, K.L. (2000). Characterization of the B lymphocyte-induced maturation protein-1 (Blimp-1) gene, mRNA isoforms and basal promoter. Nucleic Acids Res 28: 4846-4855.

TURNER, C.A., JR., MACK, D.H. and DAVIS, M.M. (1994). Blimp-1, a novel zinc finger-containing protein that can drive the maturation of $B$ lymphocytes into immunoglobulin-secreting cells. Cell 77: 297-306.

UEDA, T., ABE, K., MIURA, A., YUZURIHA, M., ZUBAIR, M., NOGUCHI, M., NIWA K., KAWASE, Y., KONO, T., MATSUDA, Y. et al. (2000). The paternal methylation imprint of the mouse $\mathrm{H} 19$ locus is acquired in the gonocyte stage during foetal testis development. Genes Cells 5: 649-659.

UTIKAL, J., MAHERALI, N., KULALERT, W. and HOCHEDLINGER, K. (2009) Sox2 is dispensable for the reprogramming of melanocytes and melanoma cells into induced pluripotent stem cells. J Cell Sci 122: 3502-3510.

UTLEY, R.T. and COTE, J. (2003). The MYST family of histone acetyltransferases. Curr Top Microbiol Immunol 274: 203-236.

VAN DEN BERG, D.L., ZHANG, W., YATES, A., ENGELEN, E., TAKACS, K. BEZSTAROSTI, K., DEMMERS, J., CHAMBERS, I. and POOT, R.A. (2008). Estrogen-related receptor beta interacts with Oct4 to positively regulate Nanog gene expression. Mol Cell Biol 28: 5986-5995.

VAN DER HEIJDEN, G.W., DERIJCK, A.A., RAMOS, L., GIELE, M., VAN DER VLAG, J. and DE BOER, P. (2006). Transmission of modified nucleosomes from the mouse male germline to the zygote and subsequent remodeling of paternal chromatin. Dev Biol 298: 458-469.

VAN DER HEIJDEN, G.W., DIEKER, J.W., DERIJCK, A.A., MULLER, S., BERDEN, J.H., BRAAT, D.D., VAN DER VLAG, J. and DE BOER, P. (2005). Asymmetry in histone $\mathrm{H} 3$ variants and lysine methylation between paternal and maternal chromatin of the early mouse zygote. Mech Dev 122: 1008-1022.

VERVOORTS, J., LUSCHER-FIRZLAFF, J.M., ROTTMANN, S., LILISCHKIS, R., 
WALSEMANN, G., DOHMANN, K., AUSTEN, M. and LUSCHER, B. (2003). Stimulation of C-MYC transcriptional activity and acetylation by recruitment of the cofactor CBP. EMBO Rep 4: 484-490.

VISWANATHAN, S.R., DALEY, G.Q. and GREGORY, R.I. (2008). Selective blockade of microRNA processing by Lin28. Science 320: 97-100.

WAKAYAMA, T., PERRY, A.C., ZUCCOTTI, M., JOHNSON, K.R. and YANAGIMACHI, R. (1998). Full-term development of mice from enucleated oocytes injected with cumulus cell nuclei. Nature 394: 369-374.

WARREN, L., MANOS, P.D., AHFELDT, T., LOH, Y.H., LI, H., LAU, F., EBINA, W., MANDAL, P.K., SMITH, Z.D., MEISSNER, A. et al. (2010). Highly efficient reprogramming to pluripotency and directed differentiation of human cells with synthetic modified mRNA. Cell Stem Cell 7: 618-30.

WEAVER, J.R., SUSIARJO, M. and BARTOLOMEI, M.S. (2009). Imprinting and epigenetic changes in the early embryo. Mamm Genome 20: 532-543.

WEBSTER, K.E., O'BRYAN, M.K., FLETCHER, S., CREWTHER, P.E., AAPOLA, U., CRAIG, J., HARRISON, D.K., AUNG, H., PHUTIKANIT, N., LYLE, R. et al. (2005). Meiotic and epigenetic defects in Dnmt3L-knockout mouse spermatogenesis. Proc Natl Acad Sci USA 102: 4068-4073.

WERNIG, M., LENGNER, C.J., HANNA, J., LODATO, M.A., STEINE, E., FOREMAN, R., STAERK, J., MARKOULAKI, S. and JAENISCH, R. (2008). A druginducible transgenic system for direct reprogramming of multiple somatic cell types. Nat Biotechnol 26: 916-924.

WERNIG, M., MEISSNER, A., FOREMAN, R., BRAMBRINK, T., KU, M., HOCHEDLINGER, K., BERNSTEIN, B.E. and JAENISCH, R. (2007). In vitro reprogramming of fibroblasts into a pluripotent ES-cell-like state. Nature 448: 318-324.

WHITELAW, E. and MARTIN, D.I. (2001). Retrotransposons as epigenetic mediators of phenotypic variation in mammals. Nat Genet 27: 361-365.

WILMUT, I., SCHNIEKE, A.E., MCWHIR, J., KIND, A.J. and CAMPBELL, K.H. (1997). Viable offspring derived from fetal and adult mammalian cells. Nature 385: 810-813.

WOLTJEN, K., MICHAEL, I.P., MOHSENI, P., DESAI, R., MILEIKOVSKY, M. HAMALAINEN, R., COWLING, R., WANG, W., LIU, P., GERTSENSTEIN, M. et al. (2009). piggyBac transposition reprograms fibroblasts to induced pluripotent stem cells. Nature 458: 766-770.

WORMAN, H.J. (2006). Inner nuclear membrane and regulation of Smad-mediated signaling. Biochim Biophys Acta 1761: 626-631.

WU, Q., BRUCE, A.W., JEDRUSIK, A., ELLIS, P.D., ANDREWS, R.M., LANGFORD, C.F., GLOVER, D.M. and ZERNICKA-GOETZ, M. (2009). CARM1 is required in embryonic stem cells to maintain pluripotency and resist differentiation. Stem Cells 27: 2637-2645.

WYKES, S.M. and KRAWETZ, S.A. (2003). The structural organization of sperm chromatin. J Biol Chem 278: 29471-29477.

XU, N., TSAI, C.L. and LEE, J.T. (2006). Transient homologous chromosome pairing marks the onset of $X$ inactivation. Science 311: 1149-1152.

YAGI, R., KOHN, M.J., KARAVANOVA, I., KANEKO, K.J., VULLHORST, D., DEPAMPHILIS, M.L. and BUONANNO, A. (2007). Transcription factor TEAD4 specifies the trophectoderm lineage at the beginning of mammalian develop- ment. Development 134: 3827-3836.

YAMANAKA, S. (2007). Strategies and new developments in the generation of patient-specific pluripotent stem cells. Cell Stem Cell 1: 39-49.

YAMANAKA, S. (2009). Elite and stochastic models for induced pluripotent stem cell generation. Nature 460: 49-52.

YANG, J., CHAI, L., FOWLES, T.C., ALIPIO, Z., XU, D., FINK, L.M., WARD, D.C and MA, Y. (2008). Genome-wide analysis reveals Sall4 to be a major regulator of pluripotency in murine-embryonic stem cells. Proc Natl Acad Sci USA 105 19756-19761.

YANG, W.C., PATEL, K.G., LEE, J., GHEBREMARIAM, Y.T., WONG, H.E., COOKE, J.P. and SWARTZ, J.R. (2009). Cell-free production of transducible transcription factors for nuclear reprogramming. Biotechnol Bioeng 104: 10471058.

YATES, A. and CHAMBERS, I. (2005). The homeodomain protein Nanog and pluripotency in mouse embryonic stem cells. Biochem Soc Trans 33: 15181521.

YOON, B.J., HERMAN, H., SIKORA, A., SMITH, L.T., PLASS, C. and SOLOWAY, P.D. (2002). Regulation of DNA methylation of Rasgrf1. Nat Genet 30: 92-96.

YU, J., VODYANIK, M.A., SMUGA-OTTO, K., ANTOSIEWICZ-BOURGET, J., FRANE, J.L., TIAN, S., NIE, J., JONSDOTTIR, G.A., RUOTTI, V., STEWART, R. et al. (2007). Induced pluripotent stem cell lines derived from human somatic cells. Science 318: 1917-1920.

YUAN, P., HAN, J., GUO, G., ORLOV, Y.L., HUSS, M., LOH, Y.H., YAW, L.P., ROBSON, P., LIM, B. and NG, H.H. (2009). Eset partners with Oct4 to restrict extraembryonic trophoblast lineage potential in embryonic stem cells. Genes Dev 23: 2507-2520.

YURKE, B., TURBERFIELD, A.J., MILLS, A.P., JR., SIMMEL, F.C. and NEUMANN, J.L. (2000). A DNA-fuelled molecular machine made of DNA. Nature 406: 605608.

ZAEHRES, H., LENSCH, M.W., DAHERON, L., STEWART, S.A., ITSKOVITZELDOR, J. and DALEY, G.Q. (2005). High-efficiency RNA interference in human embryonic stem cells. Stem Cells 23: 299-305.

ZERNICKA-GOETZ, M., MORRIS, S.A. and BRUCE, A.W. (2009). Making a firm decision: multifaceted regulation of cell fate in the early mouse embryo. Nat Rev Genet 10: 467-477.

ZHANG, J., TAM, W.L., TONG, G.Q., WU, Q., CHAN, H.Y., SOH, B.S., LOU, Y., YANG, J., MA, Y., CHAI, L. et al. (2006). Sall4 modulates embryonic stem cell pluripotency and early embryonic development by the transcriptional regulation of Pou5f1. Nat Cell Biol 8: 1114-1123.

ZHAO, X.Y., LI, W., LV, Z., LIU, L., TONG, M., HAI, T., HAO, J., GUO, C.L., MA, Q.W., WANG, L. et al. (2009). iPS cells produce viable mice through tetraploid complementation. Nature 461: 86-90.

ZHOU, W. and FREED, C.R. (2009). Adenoviral gene delivery can reprogram human fibroblasts to induced pluripotent stem cells. Stem Cells 27: 2667-2674.

ZUCCOTTI, M., PICCINELLI, A., GIORGI ROSSI, P., GARAGNA, S. and REDI, C.A. (1995). Chromatin organization during mouse oocyte growth. Mol Reprod Dev 41: 479-485. 


\section{Further Related Reading, published previously in the Int. J. Dev. Biol.}

See our recent Special Issue Placenta edited by Joan S. Hunt and Kent L. Thornburg at: http://www.ijdb.ehu.es/web/contents.php?vol=54\&issue=2-3

Modulation of mitochondrial biogenesis and bioenergetic metabolism upon in vitro and in vivo differentiation of human ES and iPS cells Alessandro Prigione and James Adjaye

Int. J. Dev. Biol. (doi: 10.1387/ijdb.103198ap)

Expression of NANOG and NANOGP8 in a variety of undifferentiated and differentiated human cells

Sakthikumar Ambady, Christopher Malcuit, Olga Kashpur, Denis Kole, William F. Holmes, Emmett Hedblom, Raymond L. Page and Tanja Dominko Int. J. Dev. Biol. (doi: 10.1387/ijdb.103192sa)

Feeder- and serum-free establishment and expansion of human induced pluripotent stem cells

Mehdi Totonchi, Adeleh Taei, Ali Seifinejad, Mohammadsharif Tabebordbar, Hassan Rassouli, Ali Farrokhi, Hamid Gourabi, Nasser Aghdami, Ghasem Hosseini-Salekdeh and Hossein Baharvand

Int. J. Dev. Biol. (2010) 54: 877-886

Analysis of SOX2 expression in developing human testis and germ cell neoplasia

Si B. Sonne, Rebecca M. Perrett, John E. Nielsen, Melissa A. Baxter, David M. Kristensen, Henrik Leffers, Neil A. Hanley and Ewa Rajpert-De-Meyts Int. J. Dev. Biol. (2010) 54: 755-760

Pluripotency of bank vole embryonic cells depends on FGF2 and activin A signaling pathways

Aneta Suwinska, Andrzej K. Tarkowski and Maria A. Ciemerych

Int. J. Dev. Biol. (2010) 54: 113-124

Foetal germ cells: striking the balance between pluripotency and differentiation

Patrick Western

Int. J. Dev. Biol. (2009) 53: 393-409

Role of polycomb proteins Ring1A and Ring1Bin the epigenetic regulation of gene expression

Miguel Vidal

Int. J. Dev. Biol. (2009) 53: 355-370

Pluripotency and differentiation in embryos and stem cells - Pavia, 17-18 January 2008

James A. Adjaye, Anne G. Byskov, Jose B. Cibelli, Ruggero De Maria, Stephen Minger, Maurilio Sampaolesi, Giuseppe Testa, Catherine Verfaillie, Magdalena Zernicka-Goetz, Hans Schöler, Michele Boiani, Nicola Crosetto and Carlo A. Redi

Int. J. Dev. Biol. (2008) 52: 801-809

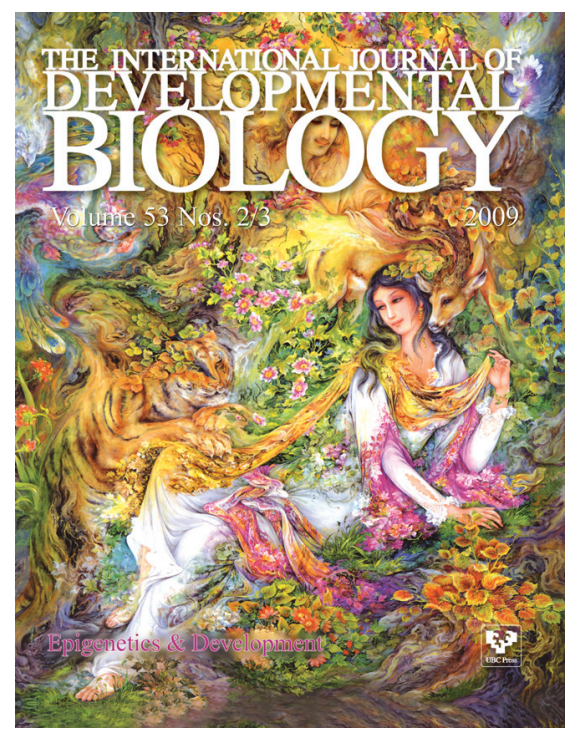

5 yr ISI Impact Factor $(2009)=3.253$

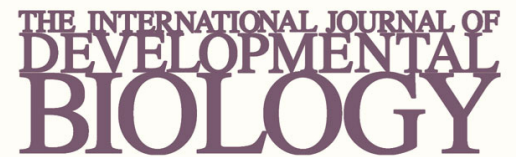

Volume 54 Nos. 6/7
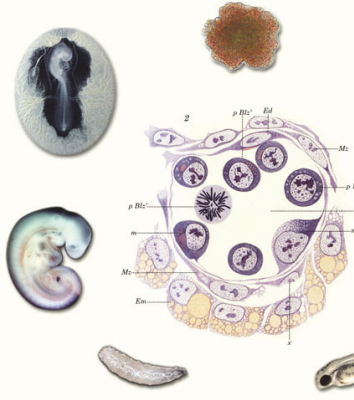

Developmental Hematopoiesis
Special Issue
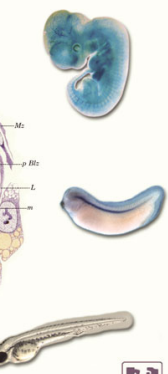

Fis

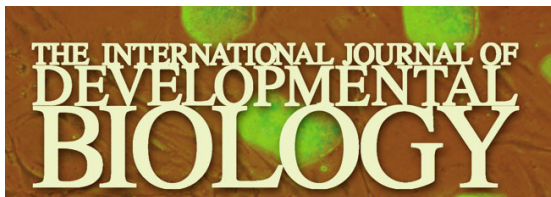

Volume 54 Nos. $11 / 12$

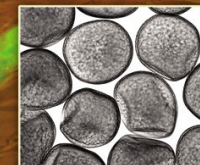

Special Issue

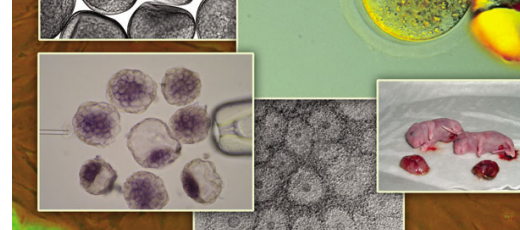

Animal Cloning \& Cell Reprooramming

\& 